\title{
Population growth, land use and land cover transformations, and water quality nexus in the Upper Ganga River basin
}

\author{
Anoop Kumar Shukla ${ }^{1}$, Chandra Shekhar Prasad Ojha ${ }^{1}$, Ana Mijic ${ }^{2}$, Wouter Buytaert ${ }^{2}$, Shray Pathak $^{1}$, \\ Rahul Dev Garg ${ }^{1}$, and Satyavati Shukla ${ }^{3}$ \\ ${ }^{1}$ Department of Civil Engineering, Indian Institute of Technology Roorkee, Uttarakhand, India \\ ${ }^{2}$ Department of Civil and Environmental Engineering, Imperial College London, London, UK \\ ${ }^{3}$ Centre of Studies in Resources Engineering (CSRE), Indian Institute of Technology Bombay, Mumbai, India
}

Correspondence: Anoop Kumar Shukla (anoopgeomatics@gmail.com)

Received: 30 June 2017 - Discussion started: 20 October 2017

Revised: 6 July 2018 - Accepted: 2 August 2018 - Published: 11 September 2018

\begin{abstract}
The Upper Ganga River basin is socioeconomically the most important river basin in India and is highly stressed in terms of water resources due to uncontrolled land use and land cover (LULC) activities. This study presents a comprehensive set of analyses to evaluate the population growth, LULC transformations, and water quality nexus for sustainable development in this river basin. The study was conducted at two spatial scales: basin scale and district scale. First, population data were analyzed statistically to study demographic changes, followed by LULC change detection over the period of February-March 2001 to 2012 (Landsat 7 Enhanced Thematic Mapper Plus (ETM+) data) using remote sensing and geographical information system (GIS) techniques. Trends and spatiotemporal variations in monthly water quality parameters, viz. biological oxygen demand (BOD), dissolved oxygen (DO, measured in percentage), fluoride $(\mathrm{F})$, hardness $\left(\mathrm{CaCO}_{3}\right), \mathrm{pH}$, total coliform bacteria and turbidity, were studied using the Mann-Kendall rank test and an overall index of pollution (OIP) developed specifically for this region, respectively. A relationship was deciphered between LULC classes and OIP using multivariate techniques, viz. Pearson's correlation and multiple linear regression. From the results, it was observed that population has increased in the river basin. Therefore, significant and characteristic LULC changes were observed. The river became polluted in both rural and urban areas. In rural areas, pollution is due to agricultural practices, mainly fertilizers, whereas in urban areas it is mainly contributed from domestic and industrial wastes. Water quality degradation has occurred in the river basin, and consequently the health status
\end{abstract}

of the river has also changed from acceptable to slightly polluted in urban areas. Multiple linear regression models developed for the Upper Ganga River basin could successfully predict status of the water quality, i.e., OIP, using LULC classes.

\section{Introduction}

Water quality is defined in terms of chemical, physical and biological (bacteriological) characteristics of the water. These characteristics may vary for different regions based on their topography, land use and land cover (LULC), and climatic factors. Demographic changes, anthropogenic activities and urbanization are potential drivers affecting the quantity and quality of available water resources on local, regional and global scales. They pose a threat to the quantity and quality of water resources, directly by increased anthropogenic water demands and water pollution. Indirectly, the water resources are affected by LULC changes and associated changes in water use patterns (Yu et al., 2016). In a region, urbanization occurs due to natural population growth and migration of people from rural to urban areas due to economic hardship (Bjorklund et al., 2011; Shukla and Gedam, 2018). It may change natural landscape characteristics and river morphometry and increase pollutant load in water bodies. Anthropogenic activities are directly correlated with decline in the water quality (Haldar et al., 2014). In order to increase crop yield, farmers introduce various chemicals in the form of fertilizers, pesticides, herbicides, etc., causing addition of pollutants to the river (Rashid and Romshoo, 2013; 
Yang et al., 2013). In urban areas, pollutants are introduced from leachates of landfill sites, stormwater runoff and direct dumping of waste (Tsihrintzis and Hamid, 1997). LULC and water quality indicator parameters are often used in water quality assessment studies (Kocer and Sevgili, 2014; Liu et al., 2016; Sanchez et al., 2007; Tu, 2011).

LULC changes may alter the chemical, physical and biological properties of a river system, e.g., biological oxygen demand (BOD), temperature, $\mathrm{pH}$, chloride $(\mathrm{Cl})$, color, dissolved oxygen (DO), hardness (measured by $\mathrm{CaCO}_{3}$ ), turbidity, total dissolved solids (TDSs). (Ballestar et al., 2003; Chalmers et al., 2007; Smith et al., 1999). Several studies have been carried out across the world to understand this phenomenon. Hong et al. (2016) studied the effects of LULC changes on the water quality of a typical inland lake of an arid region in China. The study concluded that water pollution is positively correlated to agricultural land and urban areas, whereas it is negatively correlated to water and grassland. Li et al. (2012) studied effects of LULC changes on the water quality of the Liao River basin, China. In this river basin, upstream water quality was found to be better than downstream due to less influence from LULC changes in the region. Similarly, the impact of LULC changes was studied on Likangala catchment, southern Malawi. Even though the water quality remained in an acceptable class, downstream the river was found to be polluted, with an increase in the abundance of E.Coli, cations and anions (Pullanikkatil et al., 2015). The composition and distribution of benthic macroinvertebrate assemblage were studied in the Upper Mthatha River, Eastern Cape, South Africa (Niba and Mafereka, 2015). Results revealed that the distribution of the benthic macroinvertebrate assemblage is affected by season, substrate and habitat heterogeneity. LULC changes induce changes in the river water, which affects their species distribution.

Water quality changes in the Ganga river, at various locations in Allahabad, were studied during the postmonsoon season by Sharma et al. (2014) using a water quality index (WQI) and statistical methods. Considerable water quality deterioration was observed at various locations due to the vicinity of the river to the highly urbanized city of Allahabad. A combination of water quality indices, viz. the Canadian WQI by Canadian Council of Ministers of the Environment (CCME-WQI), Oregon Water Quality Index (OWQI) and National Sanitation Foundation Water Quality Index (NSF-WQI), were used to analyze the pollution of Sapanca Lake Basin (Turkey), and a good relationship was observed between the indices and parameters. Eutrophication was identified as a major threat to Sapanca Lake and its stream system (Akkoyunlu and Akiner, 2012). A river has the capability to reduce its pollutant load, also known as selfpurification (Hoseinzadeh et al., 2014). In extreme situations, degradation of the river ecosystem caused by anthropogenic factors can be irreversible. Hence, it is crucial to understand the effects of demographic changes and LULC transforma- tions on water quality for pollution control and sustainable water resources development in a river basin (Milovanovic, 2007; Teodosiu et al., 2013).

Ganga River is extremely significant to its inhabitants as it supports various important services, such as the following: (i) being a source of irrigation for farmers in agriculture and horticulture, (ii) providing water for domestic and industrial purposes in urban areas, (iii) being a source of hydropower, (iv) serving as a drainage system for waste and helping in pollution control, (v) acting as a support system for terrestrial and aquatic ecosystems, (vi) providing religious and cultural services, (vii) helping in navigation, (viii) supporting fisheries and other livelihood options, etc. (Amarasinghe et al., 2016; SoE report, 2012; Watershed Atlas of India, 2014). However, for the past few decades the Upper Ganga River basin (UGRB) has experienced rapid growth in population, urbanization, industrialization, infrastructure development activities and agriculture. Due to these changes, maintaining the acceptable water quality for various uses is being challenged. Therefore, there is a need for a comprehensive study to understand the causative connection (nexus) between the changing patterns of population, LULC and water quality in this river basin.

Remote sensing and GIS are efficient aids in preparing and analyzing spatial datasets such as satellite data, digital elevation models (DEMs), etc. Remote sensing technology is used in preparing LULC maps of a region, whereas GIS helps in the delineation of river basin boundaries, extraction of the study area, hydrological modeling, spatiotemporal data analysis, etc. (Kindu et al., 2015; Kumar and Jhariya, 2015; Wilson, 2015). The selection of an appropriate method for a study is based on the objectives and availability of the data and tools required for the study. Ban et al. (2014) observed that water quality monitoring programs monitor and produce large and complex water quality datasets. Water quality trends vary both spatially and temporally, causing difficulty in establishing a relationship between water quality parameters and LULC changes (Phung et al., 2015; Russell, 2015). Assessment of surface water quality of a river basin can be carried out using various water quality and pollution indices based on environmental standards (Rai et al., 2011). These indices are the simplest and fastest indicators to evaluate the status of water quality in a river (Hoseinzadeh et al., 2014). Demographic growth, LULC changes and their effects on water quality in a region are very site specific. Hence, different regions and countries have developed their own water quality and pollution indices for different types of water uses based on their respective water quality standards and permissible pollution limits (Abbasi and Abbasi, 2012; Rangeti et al., 2015).

There are various water quality indices available worldwide that can be used for water quality assessment, e.g., the composite water quality identification index (CWQII) (Ban et al., 2014); river pollution index (RPI), forestry water quality index (FWQI) and NSF-WQI (Hoseinzadeh et al., 
2014), Canadian water quality index (CWQI) (Farzadkia et al., 2015), comprehensive water pollution index of China ( $\mathrm{Li}$ et al., 2015), Prati's implicit index of pollution (Prati et al., 1971), Horton's index, Nemerow and Sumitomo pollution index, Bhargava's index, Dinius second index, Smith's index, Aquatic toxicity index, Chesapeake Bay water quality indices, modified Oregon WQI, Li's regional water resource quality assessment index, Stoner's index, two-tier WQI, CCME-WQI, DELPHI water quality index, universal WQI, overall index of pollution (OIP) and coastal WQI for Taiwan (Abbasi and Abbasi, 2012; Rai et al., 2011). Currently, there is not a sufficient amount of literature available on comparisons between all the abovementioned water quality indices based on clusters, differences, validity, etc. However, in a study by Sinha and Das (2015), a comparison was made between CCME and DELPHI water quality indices based on multivariate statistical techniques, viz. coefficient of determination $\left(R^{2}\right)$, root mean square error (RMSE), and absolute average deviation. Results revealed that the DELPHI method had higher predictive capability than the CCME method. There is no universally accepted method for the development of water quality indices. Therefore, there is no established method by which $100 \%$ objectivity or accuracy can be achieved without any uncertainties. There is continuing interest across the world to develop accurate water quality indices that suit best for a local or regional area. Each water quality index has its own merits and demerits (Sutadian et al., 2016; Tyagi et al., 2013).

Water quality management and planning in a river basin requires an understanding of the cumulative pollution effect of all the water quality indicator parameters under consideration. This helps in assessing the overall water quality/pollution status of the river in a given space and time, in a specific region. In this study, a WQI called the overall index of pollution was developed specifically for Indian conditions by Sargoankar and Deshpande (2003) and is used to assess the health status of surface waters across the Upper Ganga River basin. A number of studies have successfully used OIP to assess the surface water quality of various Indian rivers. The concentration ranges used in the class indices and individual parameter indices (IPIs) assists in evaluating the changes in individual water quality parameters, whereas OIP assesses the overall water quality status of Indian rivers. This index helped to identify the parameters that are affected due to pollution from various sources. It is immensely helpful in studying the spatial and temporal variations in the surface water quality of both rural and urban subbasins due to the influence of demographic and LULC changes. The selfcleaning capacity of the river system investigated using OIP adds to the understanding of the resilience capacity of the river system against the changes occurring in water quality due to anthropogenic activities. OIP has been used successfully to study the surface water quality status of the two most important and highly polluted rivers of the tropical Indian region, viz. Ganga and Yamuna. It is also used for water quality assessment of comparatively smaller river, like the Chambal River and Sukhna lake of Chandigarh (Chardhry et al., 2013; Katyal et al., 2012; Shukla et al., 2017; Sargaonkar and Deshpande, 2003; Yadav et al., 2014). Therefore, OIP is used in the present study as an effective tool to communicate the water quality information. In the recent years, combinations of multivariate statistical techniques, e.g., Pearson's correlation, regression analyses, have been used successfully to study the links between LULC changes and water quality (Attua et al., 2014; Gyamfi et al., 2016; Hellar-Kihampa et al., 2013).

The main objective of this study is to understand the causative connection (nexus) between the changing patterns of population growth, LULC transformations, and water quality of water-stressed Upper Ganga River basin through a comprehensive set of analyses. The present study is conducted at two different spatial scales, (a) at complete river basin level (small scale) and (b) at district level (large scale), to evaluate the changes at both regional and local scales. The effect of different seasons, viz. premonsoon, monsoon and postmonsoon, on the water quality is also examined. A relationship is developed between LULC and OIP using Pearson's correlation and multiple linear regression. Findings from this research work may help engineers, planners, policy makers and different stakeholders for sustainable development in the Upper Ganga River basin.

\section{Study area}

The Upper Ganga River basin is experiencing rapid rate of change in LULC and irrigation practices. A part of the UGRB is selected as the study area (Fig. 1). It is located partly in Uttarakhand, Uttar Pradesh, Bihar and Himanchal Pradesh states of India and covers a total drainage area of $238348 \mathrm{~km}^{2}$. The geographical extent of the river basin is between $24^{\circ} 32^{\prime} 16^{\prime \prime} \mathrm{N}, 76^{\circ} 53^{\prime} 33^{\prime \prime}$ to $31^{\circ} 57^{\prime} 48^{\prime \prime} \mathrm{N}, 85^{\circ} 18^{\prime} 25^{\prime \prime} \mathrm{E}$. The altitude ranges from $7500 \mathrm{~m}$ in the Himalayan region to $100 \mathrm{~m}$ in the lower Gangetic plains. Some mountain peaks in the headwater reaches are permanently covered with snow. Annual average rainfall in the UGRB is in the range of 550-2500 $\mathrm{mm}$ (Bharati and Jayakody, 2010). Major rivers contributing to this river basin include the Bhagirathi, Alaknanda, Yamuna, Dhauliganga, Pindar, Mandakini, Nandakini, Ramganga, and Tamsa (Tons) rivers. Tehri Dam, constructed on Bhagirathi River, is one of a number of important multipurpose hydropower projects, along with several other smaller hydropower projects of low capacity. This region is comprised of major cities and towns such as Allahabad, Kanpur, Varanasi, Dehradun, Rishikesh, Haridwar, Moradabad, Bareilly Bijnor, Garhmukteshwar, Narora, Farrukhabad, Badaun, Chandausi, Amroha, Kannauj, Unnao, Fatehpur, and Mirzapur. Most predominant soil groups found in this region are alluvial, sand, loam, clay and their combinations. Due to favorable agricultural conditions majority of the population practices agriculture and horticulture. How- 
ever, a large portion of the total population lives in cities located mainly along Ganga River. Most of them work in urban or industrial areas.

\section{Data acquisition}

In this study, two types of dataset were used, which are listed below:

i. Spatial dataset. This was comprised of (a) a Shuttle Radar Topography Mission (SRTM) 1 arcsec global DEM of $30 \mathrm{~m}$ spatial resolution; (b) Landsat 7 Enhanced Thematic Mapper Plus (ETM+) images, 23 in total, for the month of February-March in 2001 and 2012, with $30 \mathrm{~m}$ spatial resolution (both the SRTM DEM and time series Landsat dataset were collected from the United States Geological Survey, USGS, 2016c); (c) Survey of India toposheets (topographical maps) of 1:50000 scale from Survey of India (SoI), Government of India (GoI); (d) published LULC, water bodies, urban land use and wasteland maps from Bhuvan Portal, Indian Space Research Organization (ISRO), GoI (Bhuvan, 2016) (SoI toposheets and published maps were used as reference to improve the LULC classification results); and (e) ground control points (GCPs) were collected using Global Positioning System (GPS) during the field visit and Google Earth (for ground truthing of prepared LULC maps).

ii. Nonspatial dataset. This was acquired from various departments of GoI: (a) census records and related reports of the years 2001 and 2011 from Census of India (Census of India, 2011); (b) reports on LULC statistics from Bhuvan Portal, ISRO, GoI; (c) monthly water quality dataset (BOD, DO, fluoride (F), hardness $\left(\mathrm{CaCO}_{3}\right)$, $\mathrm{pH}$, total coliform bacteria and turbidity) of the year 2001-2012 from Central Water Commission (CWC); and (d) water quality reports from the Central Pollution Control Board (CPCB), Uttar Pradesh Pollution Control Board (UPPCB), CWC and National Remote Sensing Centre (NRSC), ISRO, GoI.

\section{Data preparation and methodology}

\subsection{Delineation of the river basin}

This section discusses the data preparation and step-by-step methodology carried out in this study. A flowchart of the methodology is illustrated in Fig. 2. First, a field reconnaissance survey was conducted in the Upper Ganga River basin, India, to understand the study area. The global SRTM DEM (30 $\mathrm{m}$ spatial resolution) was preprocessed by filling sinks in the dataset using ArcGIS 10.1 geoprocessing tools. Further, Upper Ganga River basin boundary was delineated following a series of steps using ArcHydro tools. The following base layers were manually digitized for the study area, viz. stream network, railway lines, road network, major reservoirs, canals and settlements, using SoI topographic maps and updated further with recent available Landsat ETM+ dataset of the year 2012 .

\subsection{Population analysis}

Census of India, GoI, provided village-scale population data for rural areas and ward- and city-scale population data for urban areas for the years 2001 and 2011. Village- and wardscale population data of 77 districts, falling into Upper Ganga River basin were identified and organized into rural and urban population. Total population and population growth rate (PGR) were statistically estimated for 77 individual districts and for the complete study area over the years 2001 and 2011. Population growth rates were also estimated for rural and urban populations. In addition, the total population and population growth rates were estimated for upper and lower reaches of the study area. These comprehensive analyses were done to understand the demographic changes occurring in the study region.

\subsection{LULC mapping and change detection}

For LULC mapping and change analysis, preprocessing of the time series satellite dataset is required (Lu and Weng, 2007). The Landsat 7 ETM+ dataset of the years 2001 and 2012 were downloaded from the USGS website. Each year consisted of 23 images of the months of February-March. Images of same months were used to reduce errors in LULC change detection due to different seasons. Due to failure in the scan line corrector (SLC) of the Landsat 7 satellite, the images of the year 2012 had scan line errors, which resulted in a $22 \%$ data gap in each scene. However, despite only have $78 \%$ of data available per scene, it is one of the most radiometrically and geometrically accurate satellite datasets in the world and therefore it is still very useful for various studies (USGS, 2018). For heterogeneous regions, using a Neighbourhood Similar Pixel Interpolator (NSPI) is the simplest and most effective method to interpolate the pixel values within the gaps with high accuracy (Chen et al., 2011; Gao et al., 2016; Liu and Ding, 2017; Zhu et al., 2012; Zhu and Liu, 2014). Therefore, to correct scan line errors, Interactive Data Language (IDL) code for NSPI algorithm developed by Chen et al. (2011) was run on ENVI version 5.1. This algorithm filled the data gaps in the satellite images with high accuracy, i.e., RMSE of 0.0367 .

Further, satellite images were georeferenced to a common coordinate system, i.e., Universal Transverse Mercator Zone 43N with World Geodetic System (WGS) 1984 data for proper alignment of features in the study area. In total 75 control points were chosen from SoI toposheets of scale $1: 50000$, which were used as a base map for georectifica- 


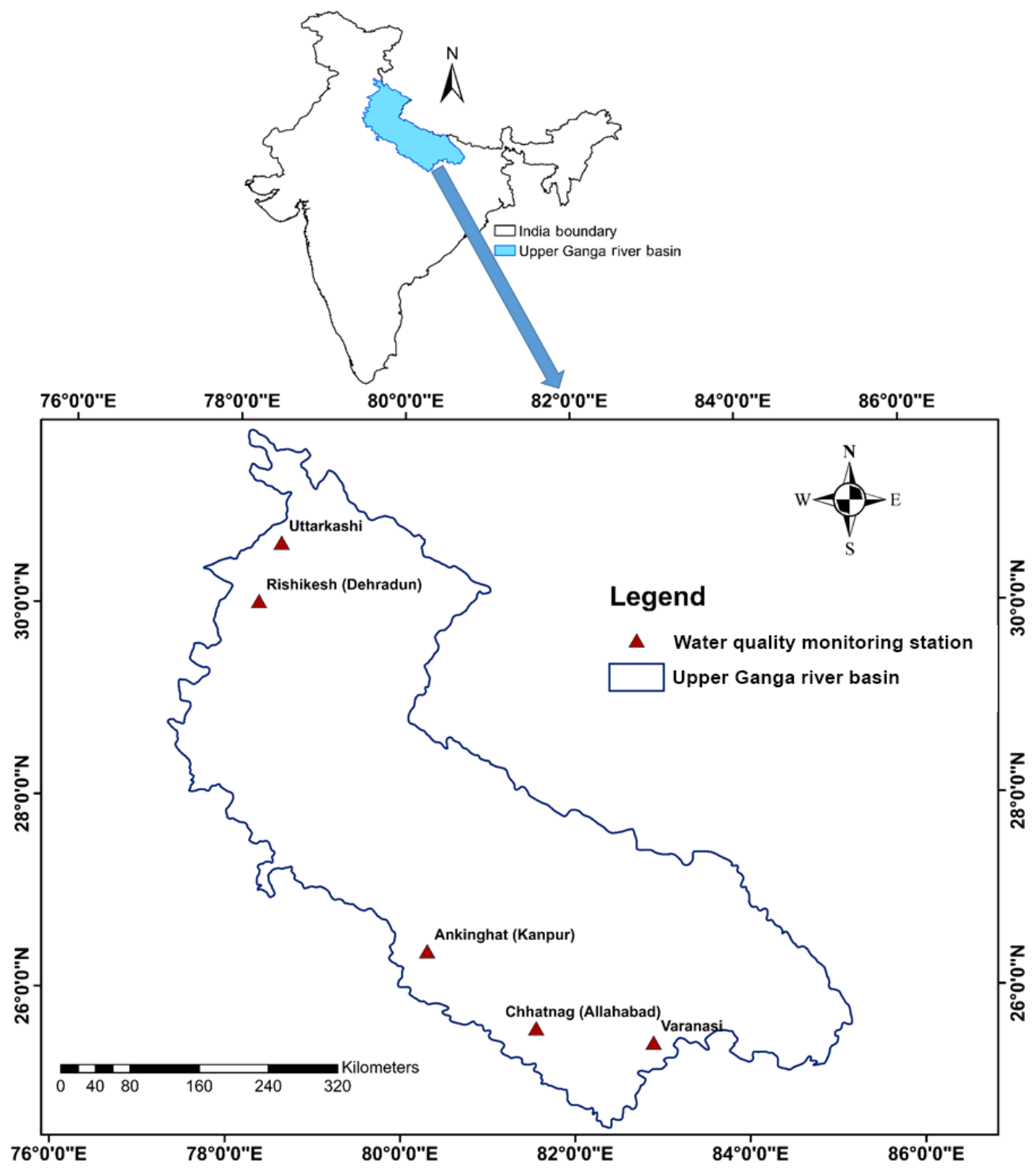

Figure 1. Location map of the study area in northern India and water quality monitoring stations across the Upper Ganga River basin.

tion. To make the two satellite images comparable, a good radiometric consistency and proper geometric alignment are required. But these are difficult to achieve due to differences in atmospheric conditions, satellite sensor characteristics, phonological characteristics, solar angle, and sensor observation angle on different images (Shukla et al., 2017). A relative geometric correction (image-to-image coregistration) method was employed to maintain geometric consistency of both the satellite images using polynomial geometric model and nearest neighbor resampling methods. The recent Landsat ETM+ image of 2012 was used as reference image for co-registration and the image of 2001 was georectified with respect to it. RMSE of less than 0.5 was used as criteria for geometric corrections of the images to ensure good accuracy (Gill et al., 2010; Samal and Gedam, 2015).
To reduce the radiometric errors and get the actual reflectance values, the Topographic and Atmospheric Correction for Airborne Imagery (ATCOR-2) algorithm available in ERDAS Imagine 2016 was used. The SRTM DEM was used to derive the characteristics, viz. slope, aspect, shadow and skyview. This algorithm provided a very good accuracy in removing haze, and in topographic and atmospheric corrections of the images (Gebremicael et al., 2017; Muriithi, 2016). Finally, an image regression method was applied to the images to normalize the variations in the pixel brightness value due to multiple scenes taken on different dates.

The images were mosaicked and study area was extracted. In total 2014 GCPs were collected from the GPS (dual frequency receiver: SOKKIA: model no. S-10) survey during the field visit and from Google Earth, with horizontal accuracy in the range of $2-5 \mathrm{~m}$. 1365 GCPs were used to train 


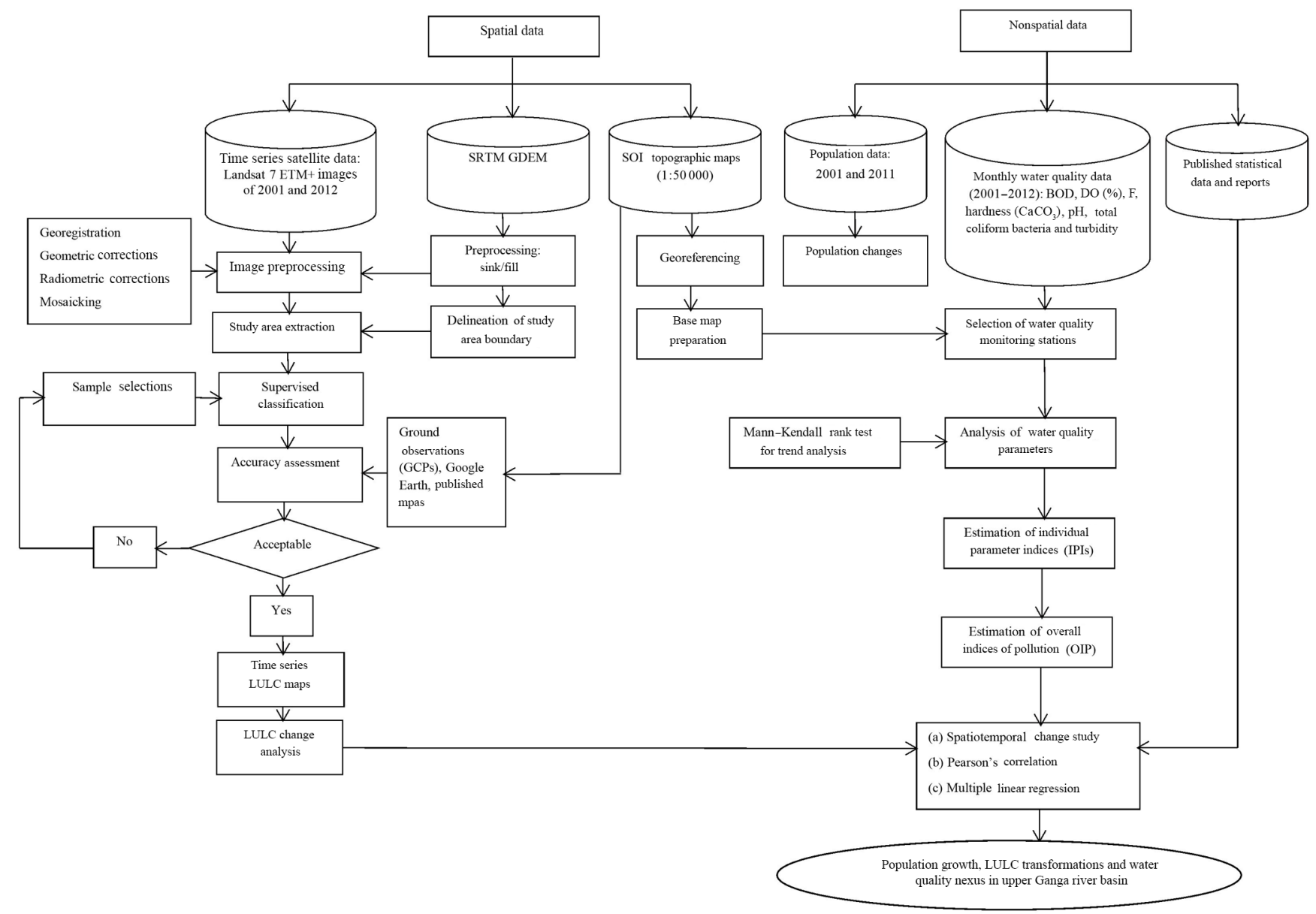

Figure 2. Flowchart illustrating methodology and steps followed in the study.

the maximum likelihood classifier (MLC) and the remaining 649 points (collected from GPS) were later used for accuracy assessment. Out of 1365 GCPs, 830 were collected using GPS survey and the remaining 535 were collected from Google Earth images. In the present study, to account for spatial autocorrelation among different LULC features, before image classification an exploratory spectral analysis was carried out using histograms of each band to understand the spectral characteristics of the LULC features. The spatial autocorrelation was analyzed using a semivariogram function, which is measured by setting variance against variable distances (Brivio et al., 1993). The estimated semivariogram was plotted to assess the spatial autocorrelation in respective bands in the satellite image. The range and shape (piecewise slope) of the semivariograms were examined visually to determine the appropriate sizes for training data, the window size and the sampling interval for spatial feature extraction (Chen, 2004; Xiaodong et al., 2009).

A window size of $7 \times 7$ was chosen for sampling the training data, which gives the better classification results on Landsat ETM+ images (Wijaya et al., 2007). While developing the spectral signatures for different LULC classes, informa- tion acquired from band histograms and Euclidean distances were used for class separability. SoI topographic maps and Google Earth images, as well as published LULC, water bodies, urban land use and wasteland maps of Bhuvan Portal were used as reference to improve the LULC classification results. Due to higher confusion between barren land and urban areas at few places, urban areas were classified independently by masking these on the image. Uncertainties in misclassification between forest and agricultural land were reduced by adding more training samples. This significantly improved the classification accuracy (Gebremicael et al., 2017). Hence, MLC of the supervised classification approach was used to classify the time series images into six LULC classes, viz. snow/glaciers, forests, built-up lands, agricultural lands, water bodies and wasteland. LULC distribution was estimated for the years 2001 and 2012. Due to lack of ground truth data of the year 2001, the accuracy assessment was done for the LULC of the year 2012. Both time series satellite dataset are from Landsat ETM+, with the same spatial resolution of $30 \mathrm{~m}$, and a large number of GCPs are available for the year 2012. Hence, the LULC map of year 2012 would represent the overall accuracy of both maps. A 
simple random sampling of 649 test pixels belonging to corresponding image objects were selected and verified against reference data.

In this sampling method, a selection of sample units was made in such a way that every possible distinct sample got an equal chance of selection. This sampling method provided comparatively better results on the large image size following the rule of thumb recommended by Congalton, i.e., a minimum of 75-100 samples should be selected per LULC category for large images (Congalton, 1991; Foody, 2002; Gonçalves et al., 2007; Hashemian et al., 2004; Kiptala et al., 2013; Samal and Gedam, 2015). Following Congalton's rule of thumb for better accuracy in simple random sampling, GCPs were selected in the range of 94-137 for each LULC class in proportion to their areal extent on the image. Therefore, sufficient spatial distribution of the sampling points was achieved for each LULC class. Accuracy assessment results were presented in a confusion matrix showing characteristic coefficients, viz. user's accuracy, producer's accuracy, overall accuracy and Kappa coefficients. The confusion matrix gave the ratio of number of correctly classified samples to the total number of samples in the reference data. The User's accuracy (errors of commission) and Producer's accuracy (errors of omission) expressed the accuracy of each LULC types, whereas the overall accuracy estimated the overall mean of user accuracy and producer accuracy (Campbell, 2007; Congalton, 1991; Jensen, 2005). The Kappa coefficient denoted the agreement between two datasets corrected for the expected agreement (Gebremicael et al., 2017). Further, a postclassification change detection method was employed for comparing the LULC maps of 2001 and 2012. This method provided comparatively, more accurate results than image difference method (Samal and Gedam, 2015). LULC distribution and change statistics between the years 2001 and 2012 were estimated for individual districts and for the complete UGRB.

\subsection{Water quality analysis}

\subsubsection{Selection of water quality monitoring stations}

To understand the impact of LULC transformations on the water quality of the UGRB, two water quality monitoring stations, viz. Uttarkashi and Rishikesh, were chosen in the upper reaches of the river basin. This part of the river basin comprises of highly undulating terrain with moderately less anthropogenic influences. Moreover, three water quality monitoring stations, viz. Ankinghat (Kanpur), Chhatnag (Allahabad) and Varanasi, were selected in the lower reaches of the river basin. This part of the river basin falls under Gangetic plains with extreme anthropogenic activities. Spatiotemporal changes in the water quality of these monitoring stations were examined over a period of the year 2001-2012 and the LULC-OIP relationship was studied using various statistical analyses, viz. Mann-Kendall rank test, OIP, Pearson's correlation and multiple linear regression.

\subsubsection{Mann-Kendall test on monthly water quality data}

A nonparametric Mann-Kendall rank test (Mann, 1945; Kendall, 1975) was performed on the seven monthly water quality parameters, viz. BOD, DO, F, hardness $\left(\mathrm{CaCO}_{3}\right)$, $\mathrm{pH}$, total coliform bacteria and turbidity, observed at the five water quality monitoring stations, to understand the existing trends in the water quality parameters of the years 2001-2012. In this test, the null hypothesis $\mathrm{H}_{0}$ assumed that there is no trend (data are independent and randomly ordered) and it was tested against the alternative hypothesis $\mathrm{H}_{1}$, which assumes that there is a trend. The standard normal deviate ( $Z$ statistic) was computed following a series of steps as given by Helsel and Hirsch (1992) and Shukla and Gedam (2018). The positive value of $Z$ test shows a rising trend and a negative value indicates a falling trend in the water quality data series. The significance of the $Z$ test was observed on confidence level of $90 \%, 95 \%$ and $99 \%$. The test was performed on monthly water quality data of January to December of the years 2001-2012. Standard deviation (SD) was estimated separately for each month.

\subsubsection{Estimation of OIP}

For a selecting water quality index, the following criteria is followed (Abbasi and Abbasi, 2012; Horton, 1965): (i) a limited number of variables should be handled by the index used to avoid making the index unwieldy; (ii) the variables used in the index should be significant in most areas; and (iii) only reliable data variables for which the data are available should be included. Hence, the seven most relevant water quality parameters in Indian context i.e., BOD, DO, total coliform (TC), F, turbidity, $\mathrm{pH}$ and hardness $\left(\mathrm{CaCO}_{3}\right)$ that are affected due to changes in LULC are chosen. BOD, DO, and TC are the parameters mainly affected by urban pollution. $\mathrm{F}$, turbidity and $\mathrm{pH}$ are general water quality parameters affected by both natural and anthropogenic factors. However, hardness $\left(\mathrm{CaCO}_{3}\right)$ is a parameter affected mainly by agricultural activities and urban pollution.

In the present study, an OIP developed by Sargaonkar and Deshpande (2003) is used that is a general water quality classification scheme developed specifically for tropical Indian conditions where, in the proposed classes $(\mathrm{C} 1$ : excellent; C2: acceptable; C3: slightly polluted; C4: polluted; and C5: heavily polluted water), the concentration levels or ranges of the significant water quality indicator parameters are defined with due consideration to the Indian water quality standards (Indian Standard Specification for Drinking Water, IS-10500, 1983; Central Pollution Control Board, Government of India, classification of inland surface water, CPCB-ADSORBS/3/78-79). Wherever the water 
Table 1. Classification scheme of water quality used in OIP (source: Sargoankar and Deshpande, 2003).

\begin{tabular}{|c|c|c|c|c|c|c|c|c|c|}
\hline \multirow[t]{2}{*}{ Classification } & \multirow[t]{2}{*}{ Class } & \multirow{2}{*}{$\begin{array}{l}\text { Class } \\
\text { index } \\
\text { (score) }\end{array}$} & \multicolumn{7}{|c|}{ Concentration limit/ranges of water quality parameters } \\
\hline & & & $\begin{array}{r}\text { BOD } \\
\left(\mathrm{mg} \mathrm{L}^{-1}\right)\end{array}$ & $\begin{array}{l}\text { DO } \\
(\%)\end{array}$ & $\begin{array}{r}\mathrm{F} \\
\left(\mathrm{mg} \mathrm{L}^{-1}\right)\end{array}$ & $\begin{array}{r}\text { Hardness } \\
\left(\mathrm{CaCO}_{3}, \mathrm{mg} \mathrm{L}^{-1}\right)\end{array}$ & $\begin{array}{r}\mathrm{pH} \\
\text { (no unit) }\end{array}$ & $\begin{array}{r}\text { Total coliform } \\
\text { (MPN per } 100 \mathrm{~mL})\end{array}$ & $\begin{array}{r}\text { Turbidity } \\
(\mathrm{NTU})\end{array}$ \\
\hline Excellent & $\mathrm{C}_{1}$ & 1 & 1.5 & $88-112$ & 1.2 & 75 & $6.5-7.5$ & 50 & 5 \\
\hline Acceptable & $\mathrm{C}_{2}$ & 2 & 3 & $75-125$ & 1.5 & 150 & $6.0-6.5$ and $7.5-8.0$ & 500 & 10 \\
\hline Slightly polluted & $\mathrm{C}_{3}$ & 4 & 6 & $50-150$ & 2.5 & 300 & $5.0-6.0$ and $8.0-9.0$ & 5000 & 100 \\
\hline Polluted & $\mathrm{C}_{4}$ & 8 & 12 & $20-200$ & 6.0 & 500 & $4.5-5$ and $9-9.5$ & 10000 & 250 \\
\hline Heavily polluted & $\mathrm{C}_{5}$ & 16 & 24 & $<20$ and $>200$ & $<6.0$ & $>500$ & $<4.5$ and $>9.5$ & 15000 & $>250$ \\
\hline
\end{tabular}

quality criteria were not defined, international water quality standards (Water quality standards of European Community (EC); World Health Organization (WHO) guidelines; standards by WQIHSR; and Tehran Water Quality Criteria by McKee and Wolf, 1963) were used. It was observed that different agencies use different indicator parameters, terminologies and definitions for classification schemes and criteria such as action level, acceptable level, guide level, and maximum allowable concentration, etc. for different uses of water. Hence, a common classification scheme was required to be defined to understand the water quality status in terms of pollution effects of the water quality parameters being considered. Table 1 illustrates the OIP classification scheme and the ranges of concentrations of the parameters under consideration. The basis on which the concentration levels for each of the parameters in the given classes are selected are described below (Sargaonkar and Deshpande, 2003):

- Turbidity. According to the Indian Standards for Drinking Water (IS-10500, 1983) and EC water quality standards, $10 \mathrm{NTU}$ is the maximum desirable level or maximum admissible level for turbidity. Therefore, in the OIP classification scheme this value is considered for class C2 (acceptable) water quality. As per WQIHSR standards and WHO Guidelines, 5 NTU is considered to be maximum acceptable level; hence, it is considered in class $\mathrm{C} 1$ (excellent). A value of 10-250 NTU is considered to be good water quality, and $>250 \mathrm{NTU}$ as poor water quality by the Wolf and McKee (1963) water quality criteria. Therefore, accordingly the turbidity is split into the following ranges: $10-100$ for class C3 (Slightly Polluted), 100-250 for class C4 (polluted) and $>250$ as class C5 (heavily polluted) water quality.

- BOD. For BOD, the classification given by Prati et al. (1971) is used, which conforms with the CPCB water quality standards, i.e., for class "A" water (drinking water) $\mathrm{BOD}$ values should be $2 \mathrm{mg} \mathrm{L}^{-1}$, and for class "B" water (outdoor bathing), BOD values should be $3 \mathrm{mg} \mathrm{L}^{-1}$. According to EC water quality standards, for freshwater fish water quality or recreational use the guide level and maximum admissible level should be 3 and $6 \mathrm{mgL}^{-1}$ respectively. And according to Mc-
Kee and Wolf (1963) water quality scheme, the BOD of $>2.5$ indicates poor water quality. Hence, in OIP classification scheme, for classes C3 (slightly polluted), C4 (polluted) and C5 (heavily polluted) water quality, the higher concentration values are assigned in geometric progression.

- DO. The maximum DO at a given space and time is the function of water temperature. It is highly variable and specific to a location. The average tropical temperature of India is $27^{\circ} \mathrm{C}$ and $8 \mathrm{mg} \mathrm{L}^{-1}$ is the corresponding average DO saturation concentration reported from studies, which represents $100 \%$ DO concentration and applies to class C1. During daytime, in eutrophic water bodies with high organic loading, very high DO concentration is observed, which is an undesirable situation. Therefore, in the OIP classification scheme for DO in a particular class, the concentration ranges on both lower and higher sides of the average DO level are considered. The ranges of DO concentration defined are illustrated in Table 1 .

- F. As fluoride is a toxic element, the classification criteria for it is more stringent. According to Indian standards for drinking water (IS 10500, 1983), the desirable limit for fluoride is $0.6-1.2 \mathrm{mg} \mathrm{L}^{-1}$, which is considered to be under class $\mathrm{C} 1$ in OIP classification scheme. According to EC standards for surface water (potable abstraction) and action level in WHO Guidelines, the mandatory limit for $\mathrm{F}$ is $1.5 \mathrm{mg} \mathrm{L}^{-1}$, which is considered the maximum level in class $\mathrm{C} 2$. A value of $1.5-$ $3.0 \mathrm{mg} \mathrm{L}^{-1}$ of $\mathrm{F}$ is considered to be good water quality but the concentration $>3.0 \mathrm{mg} \mathrm{L}^{-1}$ indicates poor water quality according to McKee and Wolf (1963) water quality standards. Hence, for class C3 (slightly polluted) water quality, the concentration value of $2.5 \mathrm{mg} \mathrm{L}^{-1}$ is used. The $\mathrm{F}$ concentration $>1.5 \mathrm{mg} \mathrm{L}^{-1}$ is bad for human health as it can result in tooth decay and further higher levels can cause bone damage through fluorosis. Therefore, concentration values of 6.0 and $>$ $6.0 \mathrm{mg} \mathrm{L}^{-1}$ are used for classes $\mathrm{C} 4$ and $\mathrm{C} 5$ respectively. 
- Hardness $\left(\mathrm{CaCO}_{3}\right)$. As per Indian standards for drinking water, the desirable limit (maximum) for hardness is $300 \mathrm{mg} \mathrm{L}^{-1}$, whereas the concentration value of $500 \mathrm{mg} \mathrm{L}^{-1}$ is indicated as action level according to WHO Guidelines. Hence, accordingly the ranges of hardness were taken as follows: class $\mathrm{C} 1$ as 0 $75 \mathrm{mg} \mathrm{L}^{-1}$, class $\mathrm{C} 2$ as $75-150 \mathrm{mg} \mathrm{L}^{-1}$, class $\mathrm{C} 3$ as $150-300 \mathrm{mg} \mathrm{L}^{-1}$, class $\mathrm{C} 4$ as $300-500 \mathrm{mg} \mathrm{L}^{-1}$ and > $500 \mathrm{mg} \mathrm{L}^{-1}$ in class $\mathrm{C} 5$.

- $p H$. According to CPCB, ADSORBS/3/78-79, a $\mathrm{pH}$ range of 6.5 to 8.5 is considered for classes A (drinking water), B (outdoor bathing) and D (propagation of wild life, fisheries, recreation and aesthetic). The EC standard guide limit for surface waters (potable abstractions) is 5.5-9.0. Hence, based on these the concentration level of $\mathrm{pH}$ in the OIP classification scheme is defined for classes C1-C5, as given in Table 1.

- Total coliform. In the given OIP scheme, for class $\mathrm{C} 1, \mathrm{C} 2$ and $\mathrm{C} 3$ the Coliform bacteria count of 50, 500 and $5000 \mathrm{MPN}$ per $100 \mathrm{~mL}$ respectively, as specified in the CPCB classification of inland surface water is considered. Coliform count ranges of 50-100, $100-5000$ and $>5000$ are considered to be excellent, good and poor water quality respectively by McKee and Wolf (1963) water quality criteria. EC bathing water standards consider a count of 10000 MPN per $100 \mathrm{~mL}$ as the maximum admissible level; therefore, the concentration range 5000-10000 is assigned to class C4, which indicates polluted water quality and makes the criteria more stringent. The count of $>10000$ indicates heavily polluted water and therefore, it was assigned to class C5.

After the concentration levels and ranges were assigned to each parameter in the given classes, the information on water quality data was transformed in discrete terms. Different water quality parameters are measured in different units. Therefore, in order to bring the different water quality parameters into a commensurate unit so that the integrated index can be obtained to be used for decision making, an integer value of $1,2,4,8$ or 16 (also known as class index score, as given in Table 1) was assigned to each class i.e., C1, C2, C3, C4 and $\mathrm{C} 5$ respectively in geometric progression. The number termed as class index indicated the pollution level of water in numeric terms and it formed the basis for comparing water quality from excellent to heavily polluted (Table 1). For each of the parameter concentration levels, the mathematical expressions were fitted to obtain this numerical value called an index $P_{\mathrm{i}}$ or IPI, which indicates the level of pollution for that particular parameter. Table 2 illustrates these mathematical equations. The value function curves, wherein, on the $Y$-axis the concentration of the parameter is taken and on the $X$-axis index value is plotted for each parameter. The figures of value function curves for important water quality parameters used in the OIP scheme can be obtained from Sargaonkar and Deshpande (2003). The value function curves provide the pollution index $P_{\mathrm{i}}$ or IPI for individual pollutants. For any particular given concentration, the corresponding index can be read directly from these curves or can be estimated using mathematical equations given for the value function curves, as illustrated in Table 2. Hence, IPIs were calculated for each parameter at a given time interval. Finally, the OIP is calculated as the mean of $P_{\mathrm{i}}$ or IPIs of all the seven water quality parameters considered in the study and mathematically it is given by expression (1):

$\mathrm{OIP}=\frac{\Sigma_{i} P_{\mathrm{i}}}{n}$,

where $P_{\mathrm{i}}$ is the pollution index for the $i$ th parameter, $i=1$, $2, \ldots, n$ and $n$ denotes the number of parameters. Finally, OIP was estimated for each water quality monitoring station across the UGRB over a period of 2001 to 2012. It gave the cumulative pollution effect of all the water quality parameters on the water quality status of a particular monitoring station at a given time. For each water quality monitoring station of the UGRB, the OIP was estimated for three primary seasons, i.e., premonsoon, monsoon and postmonsoon seasons. The interpretation of IPI values for individual parameter index or OIP values to determine the overall pollution status is carried as follows: the index value of $0-1$ (class C1) indicates excellent water quality, 1-2 (class C2) indicates acceptable, 2-4 (class C3) indicates slightly polluted, 4-8 (class C4) indicates polluted and 8-16 (class C5) indicates heavily polluted water. The upper limit of the range is to be included in that particular class. In case some additional relevant water quality parameters are required to be considered, an updated OIP can be developed using methodology given by Sargaonkar and Deshpande (2003). The mathematical value function curves can be plotted for the new parameters to get the mathematical equations, which will help to calculate IPIs. As OIP uses an additive aggregation method, the average of the IPIs of all the parameters will estimate updated OIP.

\subsection{Statistical analysis}

Due to religious, economic and historical importance of River Ganga, the most important cities and districts of the UGRB are in close proximity to the River Ganga. The water quality of selected monitoring stations is highly influenced by type of activity occurring in the district where they are located. In a study, buffer zones of different thresholds were created surrounding a water quality monitoring station to determine the dominant LULC class that affects the water quality of that particular station (Kibena et al., 2014). However, in the UGRB the population data were available at district level not at buffer level. Districts selected in this study consisted of both urban and rural areas. District-scale LULC 
Table 2. Mathematical expressions for value function curves (source: Sargoankar and Deshpande, 2003).

\begin{tabular}{llll}
\hline Serial no. & Parameter & $\begin{array}{l}\text { Concentration } \\
\text { range }\end{array}$ & Mathematical expressions \\
\hline 1 & BOD & $<2$ & $x=1$ \\
& & $2-30$ & $x=y / 1.5$ \\
2 & DO & $\leq 50$ & $x=\exp (-(y-98.33) / 36.067)$ \\
& & $50-100$ & $x=(y-107.58) / 14.667$ \\
& & $\geq 100$ & $x=(y-79.543) / 19.054)$ \\
3 & F & $0-1.2$ & $x=1$ \\
& & $1.2-10$ & $x=((y / 1.2)-0.3819) / 0.5083$ \\
4 & Hardness $\left(\mathrm{CaCO}_{3}\right)$ & $\leq 75$ & $x=1$ \\
& & $75-500$ & $x=\exp (y+42.5) / 205.58$ \\
5 & & $>500$ & $x=(y+500) / 125$ \\
& & $7>7$ & $x=1$ \\
& & $<7$ & $x=\exp ((y-7.0) / 1.082)$ \\
6 & & & $x=\exp ((7-y) / 1.082)$ \\
& & & $x=1$ \\
& & & \\
& & $50-5000$ & $x=(y / 50) \times 0.3010$ \\
7 & & $5000-15000$ & $x=((y / 50)-50) / 16.071$ \\
& & $>15000$ & $x=(y / 15000)+16$ \\
& & $\leq 10$ & $x=1$ \\
& & $10-500$ & $x=(y+43.9) / 34.5$ \\
\hline
\end{tabular}

change was extremely helpful in comprehending the water quality changes at the local scale and to identify the source of pollutants at a particular monitoring station, whereas LULC changes at the basin level provided a broad outlook on the status of water quality of the complete study area, which is also very useful for some applications. Though the spatial and mapped data could be more useful and relevant when compared with remote sensing data, the monitoring stations in the UGRB were scarce. Therefore, over a relatively large study area, the interpolation maps generated using OIP were not likely to provide very good comparison results with LULC changes. Hence, districts were chosen as a unit and district-scale population and LULC distribution were related to water quality (OIP) of the monitoring stations to comprehend the nexus between them.

Various methods and models are already developed to study effects of LULC changes on water quality. However, these methods could not be applied directly to a region because of the differences in the data availability, climatic, topographic and LULC variations that may introduce errors. Necessary modifications were made in the present evaluation methodology as required. Due to the unavailability of the continuous data on population, satellite-based LULC and water quality at desired interval in the UGRB, establishing the interrelationship between these factors is not trivial. Therefore, to develop the relationship between LULC classes and water quality (OIP), a two-time-slice analysis was done for the years 2001 and 2012, with a seasonal component. Multivariate statistical analyses, viz. Pearson's correlation and multiple linear regression, were employed between LULC classes (independent variable) and OIP (dependent variable). Pearson's Correlation determined strength of association between the variables, whereas the prediction regression model was developed using multiple linear regression.

\section{Results and discussion}

Section 5.1 presents the results of population changes in the districts of the UGRB and the complete study area. Section 5.2 presents the accuracy assessment results of LULC map, followed by Sect. 5.3, where the LULC distribution across the study area is discussed both at basin scale and at district scale. Section 5.4 presents the trend analysis results of monthly water quality data. In Sect. 5.5 the population growth, LULC transformation and water quality nexus has been described for the whole UGRB, whereas Sect. 5.6 presents it for the five districts separately. Finally, Sect. 5.7 describes the relationship between LULC and water quality (OIP).

\subsection{Population dynamics}

Analysis of the population dataset of the years 2001 and 2011 acquired from Census of India, GoI, reveals that in the UGRB, out of the 77 districts that fall in four different states, viz. Uttar Pradesh, Uttarakhand, Bihar and Himanchal Pradesh, total population and PGR has increased in 74 districts. With the majority of the districts showing a population increase, the total population of the UGRB has consequently increased (Table 3). The PGR of $20.45 \%$ 
Table 3. Table showing total population and population growth rate (PGR) in percentage in the census years 2001 and 2011.

\begin{tabular}{|c|c|c|c|c|}
\hline Serial no. & Districts & $\begin{array}{r}\text { Total population } \\
(2001)\end{array}$ & $\begin{array}{r}\text { Total population } \\
(2011)\end{array}$ & $\begin{array}{r}\text { Population growth rate } \\
\text { (PGR) } \%\end{array}$ \\
\hline 1 & Agra & 3620436 & 4418797 & 22.1 \\
\hline 2 & Aligarh & 2992286 & 3673889 & 22.8 \\
\hline 3 & Allahabad & 4936105 & 5954391 & 20.6 \\
\hline 4 & Almora & 630567 & 622506 & -1.3 \\
\hline 5 & Ambedkar Nagar & 2026876 & 2397888 & 18.3 \\
\hline 6 & Azamgarh & 3939916 & 4613913 & 17.1 \\
\hline 7 & Bageshwar & 249462 & 259898 & 4.2 \\
\hline 8 & Baghpat & 1163991 & 1303048 & 11.9 \\
\hline 9 & Bahraich & 2381072 & 3487731 & 46.5 \\
\hline 10 & Ballia & 2761620 & 3239774 & 17.3 \\
\hline 11 & Balrampur & 1682350 & 2148665 & 27.7 \\
\hline 12 & Barabanki & 2673581 & 3260699 & 22.0 \\
\hline 13 & Bareilly & 3618589 & 4448359 & 22.9 \\
\hline 14 & Basti & 2084814 & 2461056 & 18.0 \\
\hline 15 & Bhojpur & 2243144 & 2728407 & 21.6 \\
\hline 16 & Bijnor & 3131619 & 3682713 & 17.6 \\
\hline 17 & Budaun & 3069426 & 3681896 & 20.0 \\
\hline 18 & Bulandshahar & 2913122 & 3499171 & 20.1 \\
\hline 19 & Buxar & 1402396 & 1706352 & 21.7 \\
\hline 20 & Chamoli & 370359 & 391605 & 5.7 \\
\hline 21 & Champawat & 224542 & 259648 & 15.6 \\
\hline 22 & Dehradun & 1282143 & 1696694 & 32.3 \\
\hline 23 & Deoria & 2712650 & 3100946 & 14.3 \\
\hline 24 & Etah & 1561705 & 1774480 & 13.6 \\
\hline 25 & Faizabad & 2088928 & 2470996 & 18.3 \\
\hline 26 & Farrukhabad & 1570408 & 1885204 & 20.0 \\
\hline 27 & Fatehpur & 2308384 & 2632733 & 14.1 \\
\hline 28 & Firozabad & 2052958 & 2498156 & 21.7 \\
\hline 29 & Gautam Buddha Nagar & 1202030 & 1648115 & 37.1 \\
\hline 30 & Ghaziabad & 3290586 & 4681645 & 42.3 \\
\hline 31 & Ghazipur & 3037582 & 3620268 & 19.2 \\
\hline 32 & Gonda & 2765586 & 3433919 & 24.2 \\
\hline 33 & Gopalganj & 2152638 & 2562012 & 19.0 \\
\hline 34 & Gorakhpur & 3769456 & 4440895 & 17.8 \\
\hline 35 & Hardoi & 3398306 & 4092845 & 20.4 \\
\hline 36 & Haridwar & 1447187 & 1890422 & 30.6 \\
\hline 37 & Hathras & 1336031 & 1564708 & 17.1 \\
\hline 38 & Jaunpur & 3911679 & 4494204 & 14.9 \\
\hline 39 & Jyotiba Phule Nagar & 1499068 & 1840221 & 22.8 \\
\hline 40 & Kannauj & 1388923 & 1656616 & 19.3 \\
\hline 41 & Kanpur Dehat & 1563336 & 1796184 & 14.9 \\
\hline 42 & Kanpur Nagar & 4167999 & 4581268 & 9.9 \\
\hline 43 & Kaushambi & 1293154 & 1599596 & 23.7 \\
\hline 44 & Kheri & 3207232 & 4021243 & 25.4 \\
\hline 45 & Kinnaur & 78334 & 84121 & 7.4 \\
\hline 46 & Kushinagar & 2893196 & 3564544 & 23.2 \\
\hline 47 & Lucknow & 3647834 & 4589838 & 25.8 \\
\hline 48 & Maharajganj & 2173878 & 2684703 & 23.5 \\
\hline 49 & Mainpuri & 1596718 & 1868529 & 17.0 \\
\hline 50 & Mau & 1853997 & 2205968 & 19.0 \\
\hline 51 & Meerut & 2997361 & 3443689 & 14.9 \\
\hline 52 & Mirzapur & 2116042 & 2496970 & 18.0 \\
\hline 53 & Moradabad & 3810983 & 4772006 & 25.2 \\
\hline 54 & Muzaffarnagar & 3543362 & 4143512 & 16.9 \\
\hline 55 & Nainital & 762909 & 954605 & 25.1 \\
\hline
\end{tabular}


Table 3. Continued.

\begin{tabular}{|c|c|c|c|c|}
\hline Serial no. & Districts & $\begin{array}{r}\text { Total population } \\
(2001)\end{array}$ & $\begin{array}{r}\text { Total population } \\
\text { (2011) }\end{array}$ & $\begin{array}{r}\text { Population growth rate } \\
\text { (PGR) } \%\end{array}$ \\
\hline 56 & Patna & 4718592 & 5838465 & 23.7 \\
\hline 57 & Pauri Garhwal & 697078 & 687271 & -1.4 \\
\hline 58 & Pilibhit & 1645183 & 2031007 & 23.5 \\
\hline 59 & Pithoragarh & 462289 & 483439 & 4.6 \\
\hline 60 & Pratapgarh & 2731174 & 3209141 & 17.5 \\
\hline 61 & Rae Bareli & 2872335 & 3405559 & 18.6 \\
\hline 62 & Rampur & 1923739 & 2335819 & 21.4 \\
\hline 63 & Rudraprayag & 227439 & 242285 & 6.5 \\
\hline 64 & Sant Kabir Nagar & 1420226 & 1715183 & 20.8 \\
\hline 65 & Sant Ravidas Nagar & 1353705 & 1578213 & 16.6 \\
\hline 66 & Saran & 3248701 & 3951862 & 21.6 \\
\hline 67 & Shahjahanpur & 2547855 & 3006538 & 18.0 \\
\hline 68 & Shravasti & 1176391 & 1117361 & -5.0 \\
\hline 69 & Siddharthnagar & 2040085 & 2559297 & 25.5 \\
\hline 70 & Sitapur & 3619661 & 4483992 & 23.9 \\
\hline 71 & Siwan & 2714349 & 3330464 & 22.7 \\
\hline 72 & Sultanpur & 3214832 & 3797117 & 18.1 \\
\hline 73 & Tehri Garhwal & 604747 & 618931 & 2.3 \\
\hline 74 & Udhamsingh Nagar & 1235614 & 1648902 & 33.4 \\
\hline 75 & Unnao & 2700324 & 3108367 & 15.1 \\
\hline 76 & Uttarkashi & 295013 & 330086 & 11.9 \\
\hline 77 & Varanasi & 3138671 & 3676841 & 17.1 \\
\hline Total & Upper Ganga River basin & 171186859 & 206188401 & 20.45 \\
\hline
\end{tabular}

is observed in the total population of the UGRB from 2001 to 2011. Table 3 illustrates that the PGR is $\geq 20 \%$ in the districts with bigger urban agglomerations or cities, e.g., Agra, Allahabad, Bahraich, Ghaziabad, Lucknow, Kanpur (Dehat+Nagar), Varanasi, Patna. However, Almora, Pauri Garhwal and Shravasti are showing decreasing PGR. It is to be observed that these are either hilly or very small towns with poor employment opportunities. People migrate from these locations to nearby cities, thereby decreasing the PGR. It was noticed from Census of India reports that the population density of Dehradun (Rishikesh), Kanpur, Allahabad and Varanasi districts are much higher against the average population density of the Ganga River basin, i.e., $520 \mathrm{~km}^{-2}$. Varanasi is one of the most populated districts in the country.

Ganga River basin is the most sacred as well as populated river basins in India that is endowed with varying topography, climate and mineral-rich alluvial soils in the Gangetic Plains area. Due to high soil fertility in the region, $60 \%$ of the population practice agricultural activities, especially in the Gangetic Plains or lower reaches of the UGRB. This accounts for the high rural population in the region. Due to hilly terrain in the upper reaches of the basin, the population is lower compared to the lower reaches of the basin. Due to its religious and economic significance, a large number of densely populated cities and towns are located on the banks of the river mainly in the Gangetic Plain region. These cities have large growing populations and an expanding industrial sector (NRSC, 2014).

Growth rates for urban and rural areas of upper and lower reaches of the UGRB were calculated from official statistics (Fig. 3). It brings forth the clear picture of a comparatively high rise in the rural population of lower reaches. Urban population has also increased along with rural population in the lower reaches (Fig. 3a). Both rural and urban population have increased in upper reaches but the growth is relatively slower than lower reaches. However, PGR is higher in urban areas of both reaches between 2001 and 2011, which indicates urbanization of the region (Fig. 3b). After Dehradun city was declared capital of the Uttarakhand state in the year 2000 and due to subsequent industrialization in the region, the PGR of the upper reaches has increased. Hence, population rise in the UGRB is due to natural population growth and migration of the people from remote and rural areas to urban areas.

\subsection{Accuracy assessment of LULC map}

Postaccuracy assessment, the cross-tabulation (confusion matrix) of the mapped LULC classes against that observed on the ground (or reference data) for a sample of cases at specified locations are presented in Table 4. From the results it is observed that spectral confusion is common between 

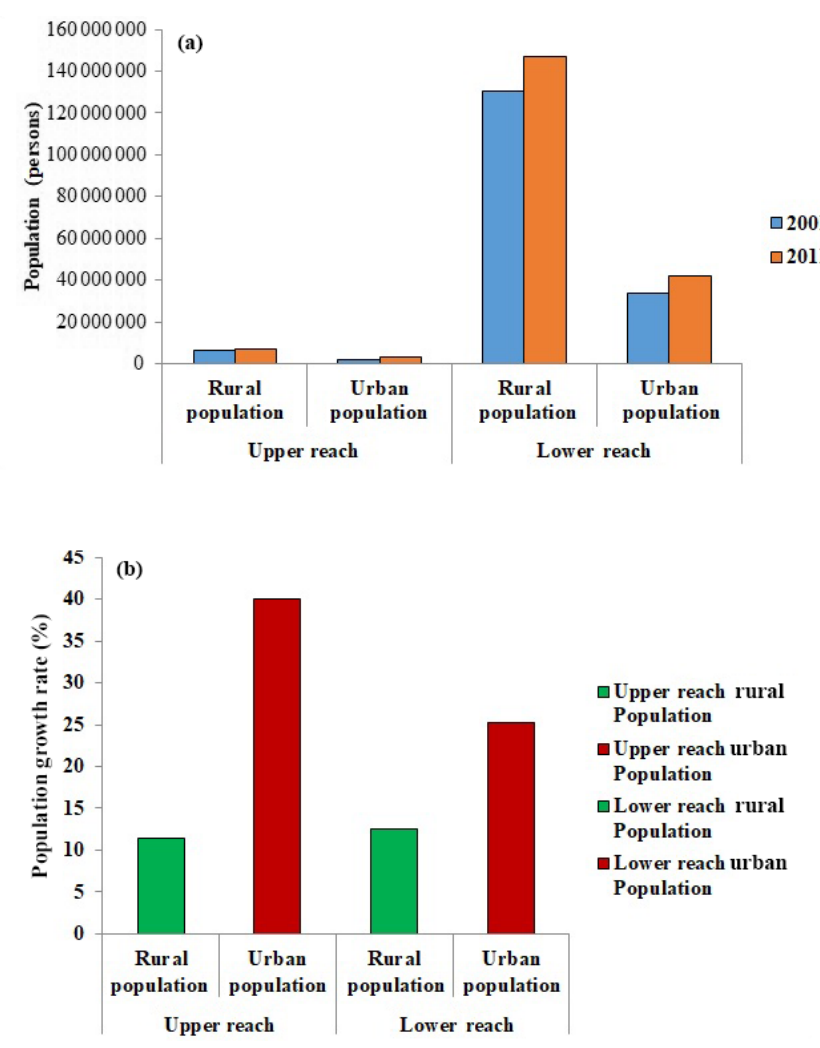

Figure 3. Growth in the rural and urban population of upper and lower reaches of the UGRB between 2001 and 2011. (a) Total population and (b) population growth rate (PGR).

few classes. For example, frozen snow/glaciers are sometimes misclassified as built-up or wasteland, whereas melted ones are misinterpreted as water bodies. Similarly, forest areas are wrongly depicted as agricultural lands on a few occasions. Sometimes barren rocky wastelands are misclassified as built-up areas, and wastelands with shrubs/grasses are misjudged as agricultural lands. Therefore, in terms of producer's accuracy all classes are over $90 \%$, except for three classes, i.e., forest, wasteland and snow/glacier, while in terms of user's accuracy, all the classes are very close to or more than $90 \%$ (Table 4). Both producer's and user's accuracy are found to be consistent for all LULC classes. For the past LULC map, a similar level of accuracy can be expected with a very little deviation. An overall classification accuracy of $90.14 \%$ was achieved with Kappa statistics of 0.88 , showing good agreement between LULC classes and reference GCPs. From the accuracy assessment results, it is evident that the present classification approach has been effective in producing LULC maps with good accuracy.

\subsection{Distribution of LULC}

The LULC maps of the UGRB for February-March 2001 and 2012 are shown in Fig. 4. District boundaries of the five districts, i.e., Uttarkashi, Dehradun, Kanpur, Allahabad
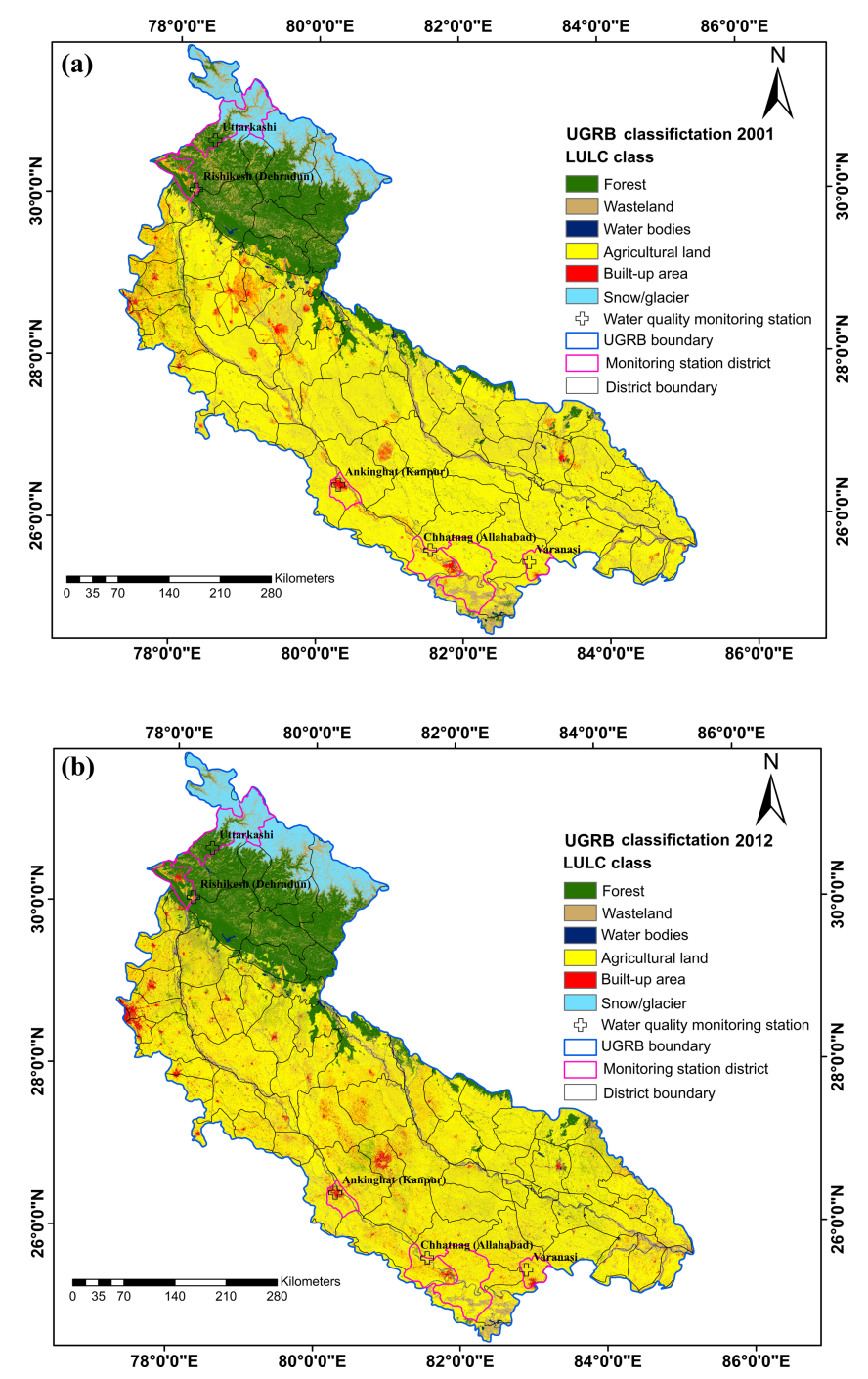

Figure 4. LULC maps of Upper Ganga River basin. (a) LULC map of February-March 2001 and (b) LULC map of February-March 2012.

and Varanasi, chosen for district-scale LULC analysis are highlighted in this figure. The gross percentage area in each LULC class and their changes from 2001 to 2012 in the UGRB are illustrated in Fig. 5. From the results it is observed that the agricultural lands, built-up, forest and snow/glaciers have increased, whereas the water bodies and wasteland have decreased. The highest percentage change is observed in the built-up class, which has increased by $43.4 \%$. In 2001 , $17.1 \%$ of wastelands were present in the study area, which have reduced to $11.4 \%$. Therefore, the wastelands are the second most dynamic category, with the significant decrease of $33.6 \%$. Agriculture land, forest and snow/glaciers have also increased by $2.9 \%, 14.5 \%$ and $1.1 \%$ respectively. Conversely, water bodies have decreased from $2.0 \%$ in 2001 to $1.8 \%$ in 2012 (Fig. 5). 
Table 4. Accuracy assessment of the 2012 LULC map produced from Landsat ETM+ data, representing both the confusion matrix and the Kappa statistics. The bold values highlight the number of GCPs selected in each LULC class and total number of GCPs used in the accuracy assessment of the 2012 LULC map. AG = agricultural land, BU = built-up, $\mathrm{F}=$ forest, $\mathrm{SG}=$ snow $/$ glacier, $\mathrm{WL}=$ wasteland and $\mathrm{WB}=$ water bodies.

\begin{tabular}{|c|c|c|c|c|c|c|c|c|c|}
\hline \multirow{2}{*}{$\begin{array}{l}\text { Classified } \\
\text { data }\end{array}$} & \multicolumn{6}{|c|}{ Reference data } & \multirow[t]{2}{*}{ Row total } & \multirow{2}{*}{$\begin{array}{r}\text { User's } \\
\text { accuracy (\%) }\end{array}$} & \multirow{2}{*}{$\begin{array}{r}\text { Overall Kappa } \\
\text { statistics }\end{array}$} \\
\hline & AG & $\mathrm{BU}$ & F & SG & WL & WB & & & \\
\hline AG & 128 & 0 & 6 & 0 & 3 & 0 & 137 & 93.43 & 0.88 \\
\hline BU & 2 & 96 & 2 & 5 & 1 & 0 & 106 & 90.57 & \\
\hline $\mathrm{F}$ & 11 & 0 & 88 & 3 & 0 & 3 & 105 & 83.81 & \\
\hline SG & 0 & 4 & 1 & 103 & 2 & 1 & 111 & 92.79 & \\
\hline WL & 1 & 2 & 0 & 7 & 82 & 2 & 94 & 87.23 & \\
\hline WB & 0 & 0 & 1 & 1 & 6 & 88 & 96 & 91.67 & \\
\hline $\begin{array}{l}\text { Column } \\
\text { Total }\end{array}$ & 142 & 102 & 98 & 119 & 94 & 94 & 649 & & \\
\hline $\begin{array}{l}\text { Producer's } \\
\text { accuracy }(\%)\end{array}$ & 90.14 & 94.12 & 89.80 & 86.55 & 87.23 & 93.62 & & & \\
\hline $\begin{array}{l}\text { Overall } \\
\text { classification } \\
\text { accuracy }(\%)\end{array}$ & & & & & 90.14 & & & & \\
\hline
\end{tabular}

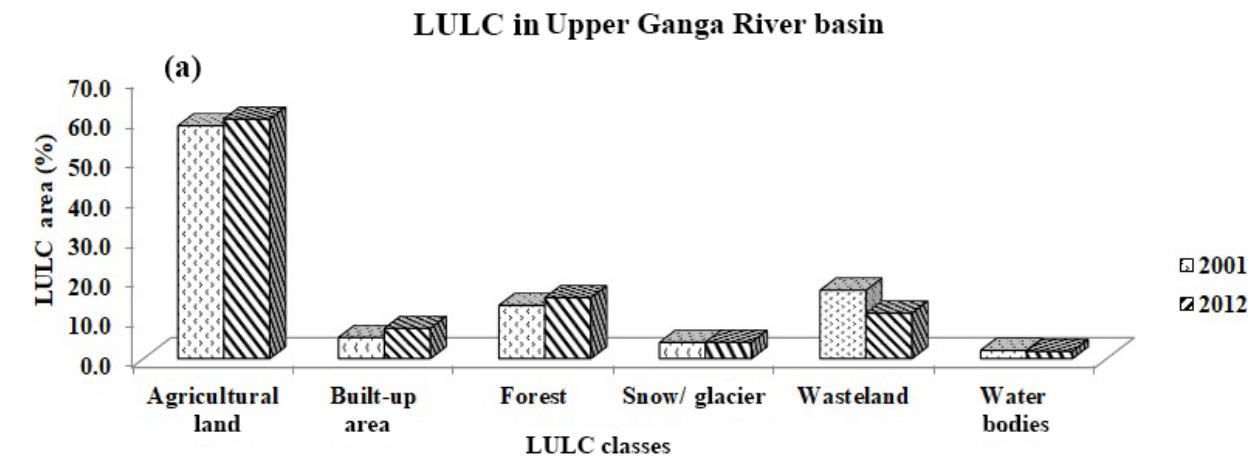

LULC changes from 2001-2012 in Upper Ganga River basin

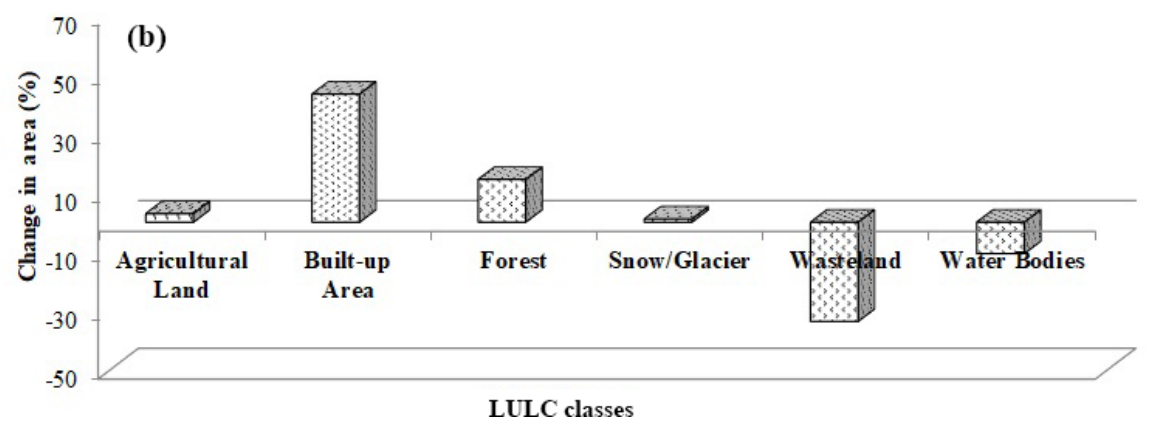

Figure 5. Graph showing LULC distribution of the years 2001-2012. (a) LULC area in percentage (\%) and (b) LULC changes from 2001 to 2012 in Upper Ganga River basin. 
Table 5. Change matrix showing LULC interconversion between the year 2001 and 2012 in Upper Ganga River basin. Figures indicate the percentage $(\%)$ of basin area.

\begin{tabular}{lrrrrrrr}
\hline LULC class & F & WL & WB & AG & BU & SG & $\begin{array}{r}\text { LULC } \\
2001\end{array}$ \\
\hline F & 13.3 & 0.0 & 0.0 & 0.0 & 0.0 & 0.0 & 13.3 \\
WL & 1.7 & 11.4 & 0.0 & 1.7 & 2.2 & 0.1 & 17.1 \\
WB & 0.2 & 0.0 & 1.8 & 0.0 & 0.0 & 0.0 & 2.0 \\
AG & 0.0 & 0.0 & 0.0 & 58.3 & 0.0 & 0.0 & 58.3 \\
BU & 0.0 & 0.0 & 0.0 & 0.0 & 5.3 & 0.0 & 5.3 \\
SG & 0.0 & 0.0 & 0.0 & 0.0 & 0.0 & 4.0 & 4.0 \\
\hline LULC 2012 & 15.2 & 11.4 & 1.8 & 60.0 & 7.5 & 4.1 & 100.0 \\
\hline
\end{tabular}

Table 5 presents the change matrix, showing the conversion of one LULC class to another between the years 2001 to 2012. Results reveal that $1.7 \%, 1.7 \%, 2.2 \%$ and $0.1 \%$ of the wastelands in the basin area have converted to forest, agricultural land, built-up and snow/glaciers respectively. Therefore, significant increases in these LULC classes are observed in the UGRB on the expanse of wastelands, resulting in high water demand. With increase in agricultural lands and builtup, water requirements have increased in the river basin to meet irrigation, domestic and industrial water demands of rural and urban regions. About $0.2 \%$ of the water bodies in the region are converted to forest during the summer season due to natural vegetation growth. Forest areas have also increased in the region due to the implementation of various government policies for forest protection and reforestation. Hence, a slight reduction and increase in the water bodies and forest classes are observed respectively.

District-scale LULC change studies are useful in comprehending the link between LULC and water quality at the local scale, and in identifying the source of pollutants at a particular monitoring station. Table 6 presents the LULC statistics of the five districts from 2001 to 2012, where water quality monitoring stations are located. It shows increase in builtup and agricultural lands in all the districts, whereas wastelands have decreased. Forest areas have increased slightly in Uttarkashi and Varanasi, although they have remained unchanged in the remaining districts. The snow/glacier class is only present in Uttarkashi district and it has slightly increased from 2001 to 2012. Water bodies have increased slightly in all the districts except Dehradun where it has reduced slightly. Hence, significant LULC changes are observed in the UGRB at both basin and district scales.

\subsection{Trend analysis on monthly water quality data}

From the results of trend analysis (Mann-Kendall rank test) it is observed that each water quality parameter varies with time and location, and hence the changes in the water quality parameters are observed in all the months (Table 7). No regular trends are observed in the water quality data; therefore,
Table 6. District-scale changes in LULC in (a) Uttarkashi, (b) Dehradun, (c) Kanpur, (d) Allahabad and (e) Varanasi.

\begin{tabular}{|c|c|c|c|}
\hline LULC class & $2001 \%$ & $2012 \%$ & $\begin{array}{r}\% \text { change } \\
(2001-2012)\end{array}$ \\
\hline \multicolumn{4}{|l|}{ (a) Uttarkashi } \\
\hline Forest & 39.3 & 39.7 & 1.1 \\
\hline Wasteland & 10.3 & 8.3 & -19.3 \\
\hline Water bodies & 1.4 & 1.5 & 4.6 \\
\hline Agricultural land & 0.6 & 1.4 & 122.8 \\
\hline Built-up area & 0.2 & 0.6 & 186.3 \\
\hline Snow and glacier & 48.2 & 48.6 & 0.8 \\
\hline Total area & 100.0 & 100.0 & \\
\hline \multicolumn{4}{|l|}{ (b) Dehradun } \\
\hline Forest & 59.8 & 59.8 & 0.1 \\
\hline Wasteland & 18.8 & 3.4 & -82.1 \\
\hline Water bodies & 4.8 & 4.3 & -9.8 \\
\hline Agricultural land & 13.5 & 20.3 & 50.6 \\
\hline Built-up area & 3.2 & 12.2 & 283.9 \\
\hline Total area & 100.0 & 100.0 & \\
\hline \multicolumn{4}{|l|}{ (c) Kanpur } \\
\hline Forest & 0.3 & 0.3 & 8.7 \\
\hline Wasteland & 23.4 & 4.7 & -79.8 \\
\hline Water Bodies & 2.5 & 2.6 & 3.8 \\
\hline Agricultural land & 63.7 & 67.0 & 5.2 \\
\hline Built-up area & 10.1 & 25.3 & 152.1 \\
\hline Total area & 100.0 & 100.0 & \\
\hline \multicolumn{4}{|l|}{ (d) Allahabad } \\
\hline Forest & 1.5 & 1.5 & -1.2 \\
\hline Wasteland & 22.1 & 16.0 & -27.8 \\
\hline Water bodies & 3.0 & 3.1 & 1.3 \\
\hline Agricultural land & 70.5 & 73.4 & 4.2 \\
\hline Built-up area & 2.8 & 6.0 & 111.7 \\
\hline Total area & 100.0 & 100.0 & \\
\hline
\end{tabular}

\begin{tabular}{lrrr}
\hline (e) Varanasi & & & \\
\hline Forest & 0.6 & 0.7 & 24.4 \\
Wasteland & 16.8 & 6.0 & -64.5 \\
Water bodies & 3.1 & 3.3 & 7.1 \\
Agricultural land & 76.8 & 79.4 & 3.4 \\
Built-up area & 2.7 & 10.5 & 291.8 \\
\hline Total area & 100.0 & 100.0 & \\
\hline
\end{tabular}

they are very site specific. Results from statistical analyses reflect that comparatively high SD and significant changes are observed in water quality of the monsoon month (July), which is followed by premonsoon and postmonsoon months in decreasing order. The effect of different seasons on water quality is reported from various studies (Islam et al., 2017; Sharma and Kansal, 2011; Singh and Chandna, 2011). In 


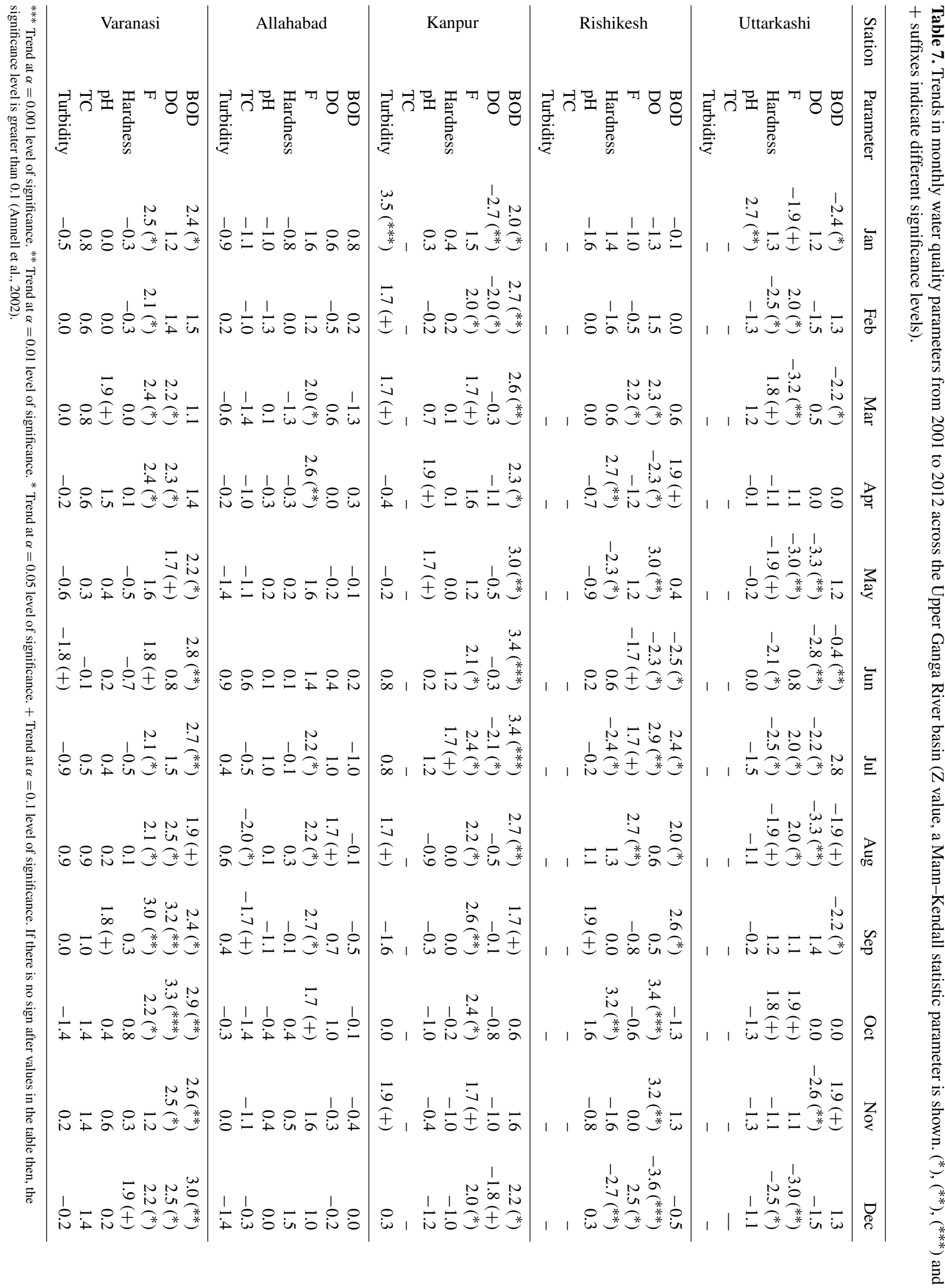


this study, three significant seasons are identified and hence the water quality data are organized into three groups: premonsoon season (February-May), monsoon season (JuneSeptember) and postmonsoon season (October-January).

From each group, one representative month, i.e., May, July or November, is chosen, which represents that particular season the best. It reduced the redundancy of the dataset and avoided the confusion that can be caused by a large insignificant dataset of varying trends that makes no sense. For example, SD values in BOD of Kanpur station in May, July and November are 2.01, 2.67 and 1.04 respectively. In other months, the SD value of the BOD is close to the SD value of the representative months. In addition, from Table 7 it is evident that trends for BOD and turbidity in July are significant for almost all the stations against other water quality parameters. They are increasing over the years from 2001 to 2012. Premonsoon (May) data signify the water quality pollution from point sources of pollution from various sewage drains and industrial effluents. In addition to the point sources of pollution, monsoon (July) data took into account the nonpoint source of pollution, e.g., discharge of surface runoff from urban areas into the nearby streams during rainfall. Postmonsoon (November) data help to understand the water quality condition of the rivers after the rainfall is over. Therefore, in this study, further water quality data analysis was done for the same three representative months.

\subsection{State of the population growth, LULC transformations and water quality nexus in the UGRB}

In this section, the association between the three components population growth, LULC transformations and water quality are established. Seasonal water quality parameter values for UGRB over the periods of 2001-2012 are presented in Table 8 . Their respective IPI values and OIP for each monitoring station are illustrated in Table 9. In the UGRB the population increase in both rural and urban areas has resulted in significant changes in LULC distribution. Increase in PGR of $20.45 \%$ in the complete basin has resulted in increases of $43.4 \%$ and $2.9 \%$ in urban and rural areas respectively. Therefore, this river basin is urbanizing gradually with increases in industrial operations. Urbanization, industrialization and intense agricultural activities have caused water quality degradation between the periods of 2001 and 2012. Nearly all the parameters are relatively higher in July, which is during the rainy season. Hence, their subsequent IPI values and resulting OIP are also high in this month. Hardness $\left(\mathrm{CaCO}_{3}\right)$ and $\mathrm{pH}$ values are higher in monsoon months as bicarbonates, hydroxides and phosphates from rock weathering are transported to the river water by surface runoff. Turbidity is also high due to the addition of organic matter from land surfaces to the nearby stream through surface runoff. $F$ is introduced into the river by surface runoff carrying $\mathrm{F}$ from industrial regions. High DO values are attributed to increased diffusion of oxygen into the water during increased stream flow caused by storm events. Increases in BOD and total coliform bacteria are a result of increased transportation of municipal sewage containing organic matter and various strains of coliform bacteria. Similar results were reported from the studies done by various researchers (Attua et al., 2014; Chapman, 1992; Hellar-Kihampa et al., 2013; Jain et al., 2006).

In the UGRB, the population growth and LULC transformations are lower in the upper reaches therefore the water quality of the monitoring stations located in this region (Uttarkashi and Rishikesh) has remained in the acceptable class range (OIP: 1.38-1.58) from 2001 to 2012. Conversely, in the lower reaches, the water quality has deteriorated from the acceptable class to the slightly polluted class (OIP: 1.872.79) at the monitoring stations (Ankinghat, Chhatnag and Varanasi) due to increased pollutants in the river water from urban, agriculture and industrial sectors (Fig. 6 and Table 9). Further, explanation on the connection between population growth, LULC transformations and water quality in the UGRB is given at the district or local scale in Sect. 5.6.

\subsection{State of the population growth, LULC transformations and water quality nexus in the districts of the UGRB}

Besides analysis at complete river basin level, the district level studies are also important. Each district has different topography, climate, population and LULC distribution. Therefore, the water management strategies in these districts should be based on the sources of pollutants and the health status of the river. Spatiotemporal variations in the water quality of the UGRB are studied using OIPs for three different seasons, viz. premonsoon (May), monsoon (July) and postmonsoon (November), from the years 2001-2012. Rainfall amount, duration and intensity are important drivers affecting surface water quality parameters of a water body primarily during monsoon and postmonsoon seasons. For example OIP at Ankinghat (Kanpur) has slightly increased from 2.51 in premonsoon season to 2.79 in monsoon season in the year 2012. In postmonsoon season, it has further decreased to 2.77. Similarly, at Chhatnag (Allahabad) station higher OIP (2.23) is noticed in monsoon season than in another two stations in the year 2012 (Table 9). Other factors such as type of LULC, type of soils, amount and type of waste generation, treatment facilities, etc. also affect the water quality. At Varanasi station, OIP values are higher in premonsoon season (2.28) than in another two seasons in 2012. Reduced values in monsoon season are probably due to relatively lower rainfall at this station. It indicates high influence of anthropogenic activities on the river water than natural drivers such as rainfall. But at the same station, in the year 2001 the OIP values were higher in monsoon season (2.08) than in other remaining seasons. Hence, high spatiotemporal variations are observed in the water quality status of the river (Table 9). Water quality parameters, viz. hardness $\left(\mathrm{CaCO}_{3}\right), \mathrm{F}, \mathrm{pH}$ and 
Table 8. Water quality parameters across the Upper Ganga River basin for premonsoon, monsoon and postmonsoon seasons over periods of 2001-2012. Units: $\mathrm{BOD}=\mathrm{mg} \mathrm{L}^{-1}$; $\mathrm{DO}=\% ; \mathrm{F}=\mathrm{mg} \mathrm{L}^{-1}$; hardness $\left(\mathrm{CaCO}_{3}\right)=\mathrm{mg} \mathrm{L}^{-1} ; \mathrm{pH}=$ no unit; total coliform $=\mathrm{MPN}$; turbidity $=$ NTU.

\begin{tabular}{|c|c|c|c|c|c|c|c|c|c|c|c|c|c|c|c|}
\hline \multirow[t]{3}{*}{ Parameters } & \multicolumn{15}{|c|}{ Water quality monitoring stations } \\
\hline & \multicolumn{3}{|c|}{ Uttarkashi } & \multicolumn{3}{|c|}{ Rishikesh } & \multicolumn{3}{|c|}{ Kanpur } & \multicolumn{3}{|c|}{ Allahabad } & \multicolumn{3}{|c|}{ Varanasi } \\
\hline & May & Jul & Nov & May & Jul & Nov & May & Jul & Nov & May & Jul & Nov & May & Jul & Nov \\
\hline \multicolumn{16}{|l|}{ (a) Year 2001} \\
\hline BOD & 1.1 & 1.1 & 1.1 & 1.1 & 1.0 & 1.1 & 2.8 & 1.7 & 2.4 & 4.0 & 4.2 & 3.7 & 2.5 & 2.2 & 1.8 \\
\hline DO & 88 & 104 & 89 & 71 & 60 & 64 & 89 & 96 & 93 & 92 & 84 & 95 & 90 & 92 & 85 \\
\hline $\mathrm{F}$ & 0.19 & 0.04 & 0.22 & 0.23 & 0.16 & 0.26 & 0.61 & 0.21 & 0.34 & 0.09 & 0.50 & 0.51 & 0.3 & 0.05 & 0.51 \\
\hline Hardness $\left(\mathrm{CaCO}_{3}\right)$ & 65 & 60 & 68 & 76 & 67 & 74 & 99 & 78 & 86 & 95 & 194 & 159 & 99 & 176 & 142 \\
\hline $\mathrm{pH}$ & 8.1 & 8.1 & 8.1 & 8.1 & 8.1 & 8.1 & 8.0 & 8.3 & 8.1 & 8.2 & 8.3 & 8.2 & 8.2 & 8.4 & 8.2 \\
\hline Total coliform & - & - & - & - & - & - & - & - & - & 3000 & 6200 & 6500 & 5100 & 5300 & 2400 \\
\hline Turbidity & - & - & - & - & - & - & 2.0 & 3.1 & 2.3 & 0.1 & 0.2 & 0.1 & 0.1 & 0.1 & 0.1 \\
\hline \multicolumn{16}{|l|}{ (b) Year 2012} \\
\hline BOD & 1.1 & 1.2 & 1.0 & 1.0 & 1.2 & 1.2 & 7.0 & 10.0 & 4.0 & 2.9 & 3.2 & 2.4 & 3.0 & 3.9 & 2.9 \\
\hline DO & 73 & 64 & 73 & 81 & 75 & 77 & 86 & 75 & 90 & 85 & 108 & 98 & 101 & 98 & 98 \\
\hline $\mathrm{F}$ & 0.45 & 0.26 & 0.44 & 0.09 & 0.19 & 0.06 & 0.70 & 0.80 & 0.51 & 0.51 & 0.67 & 0.56 & 0.57 & 0.54 & 0.52 \\
\hline Hardness $\left(\mathrm{CaCO}_{3}\right)$ & 45 & 24 & 34 & 33 & 23 & 56 & 110 & 102 & 90 & 97 & 85 & 92 & 89 & 75 & 81 \\
\hline $\mathrm{pH}$ & 7.8 & 7.7 & 7.6 & 7.8 & 8.0 & 7.8 & 8.7 & 8.4 & 8.1 & 8.2 & 8.5 & 8.2 & 8.7 & 8.4 & 8.7 \\
\hline Total coliform & - & - & - & - & - & - & - & - & - & 5200 & 5800 & 4600 & 5600 & 7300 & 4700 \\
\hline Turbidity & - & - & - & - & - & - & 4.0 & 6.0 & 5.4 & 0.1 & 0.5 & 0.1 & 0.1 & 0.2 & 0.1 \\
\hline
\end{tabular}

Table 9. Individual parameter indices (IPIs) and overall indices of pollution (OIPs) computed at various water quality monitoring stations of the Upper Ganga River basin over periods of 2001 and 2012 for premonsoon, monsoon and postmonsoon seasons. Bold IPI and italic OIP values are significant.

\begin{tabular}{|c|c|c|c|c|c|c|c|c|c|c|c|c|c|c|c|}
\hline \multirow[t]{3}{*}{ Parameters } & \multicolumn{15}{|c|}{ Water quality monitoring stations } \\
\hline & \multicolumn{3}{|c|}{ Uttarkashi } & \multicolumn{3}{|c|}{ Rishikesh } & \multicolumn{3}{|c|}{ Kanpur } & \multicolumn{3}{|c|}{ Allahabad } & \multicolumn{3}{|c|}{ Varanasi } \\
\hline & May & Jul & Nov & May & Jul & Nov & May & Jul & Nov & May & Jul & Nov & May & Jul & Nov \\
\hline \multicolumn{16}{|l|}{ (a) } \\
\hline BOD & 1.00 & 1.00 & 1.00 & 1.00 & 1.00 & 1.00 & 2.87 & 2.40 & 2.60 & 2.67 & 2.80 & 2.47 & 1.67 & 1.47 & 1.20 \\
\hline DO $(\%)$ & 1.33 & 1.28 & 1.27 & 2.49 & 3.24 & 2.97 & 1.27 & 0.79 & 0.99 & 1.06 & 1.61 & 0.86 & 1.20 & 1.06 & 1.54 \\
\hline Hardness $\left(\mathrm{CaCO}_{3}\right)$ & 1.00 & 1.00 & 1.00 & 1.78 & 1.00 & 1.00 & 1.99 & 1.80 & 1.87 & 1.95 & 3.16 & 2.66 & 1.99 & 2.89 & 2.45 \\
\hline $\mathrm{pH}$ & 2.76 & 2.76 & 2.76 & 2.76 & 2.76 & 2.76 & 2.52 & 3.33 & 2.76 & 3.03 & 3.33 & 3.03 & 3.03 & 3.65 & 3.03 \\
\hline Total coliform & - & - & - & - & - & - & - & - & - & 3.43 & 4.60 & 4.98 & 4.02 & 3.48 & 3.21 \\
\hline Turbidity & - & - & - & - & - & - & 1.00 & 1.00 & 1.00 & 1.00 & 1.00 & 1.00 & 1.00 & 1.00 & 1.00 \\
\hline OIP (2001) & 1.42 & 1.41 & 1.41 & 1.81 & 1.80 & 1.75 & 2.61 & 2.49 & 2.54 & 2.02 & 2.50 & 2.29 & 1.99 & 2.08 & 1.92 \\
\hline $\mathrm{F}$ & 1.00 & 1.00 & 1.00 & 1.00 & 1.00 & 1.00 & 1.00 & 1.00 & 1.00 & 1.00 & 1.00 & 1.00 & 1.00 & 1.00 & 1.00 \\
\hline Hardness $\left(\mathrm{CaCO}_{3}\right)$ & 1.00 & 1.00 & 1.00 & 1.00 & 1.00 & 1.00 & 2.10 & 2.02 & 2.91 & 1.97 & 1.86 & 1.92 & 1.90 & 1.00 & 1.82 \\
\hline $\mathrm{pH}$ & 2.09 & 1.91 & 1.74 & 2.09 & 2.52 & 2.09 & 4.81 & 3.65 & 2.76 & 3.03 & 4.00 & 3.03 & 4.81 & 3.65 & 4.81 \\
\hline Total coliform & - & - & - & - & - & - & - & - & - & 4.05 & 4.11 & 3.90 & 4.14 & 5.97 & 3.93 \\
\hline Turbidity & - & - & - & - & - & - & 1.00 & 1.20 & 1.08 & 1.00 & 1.00 & 1.00 & 1.00 & 1.00 & 1.00 \\
\hline OIP (2012) & 1.49 & 1.58 & 1.42 & 1.38 & 1.55 & 1.44 & 2.51 & 2.79 & 2.77 & 2.07 & 2.23 & 1.87 & 2.28 & 2.27 & 2.16 \\
\hline
\end{tabular}



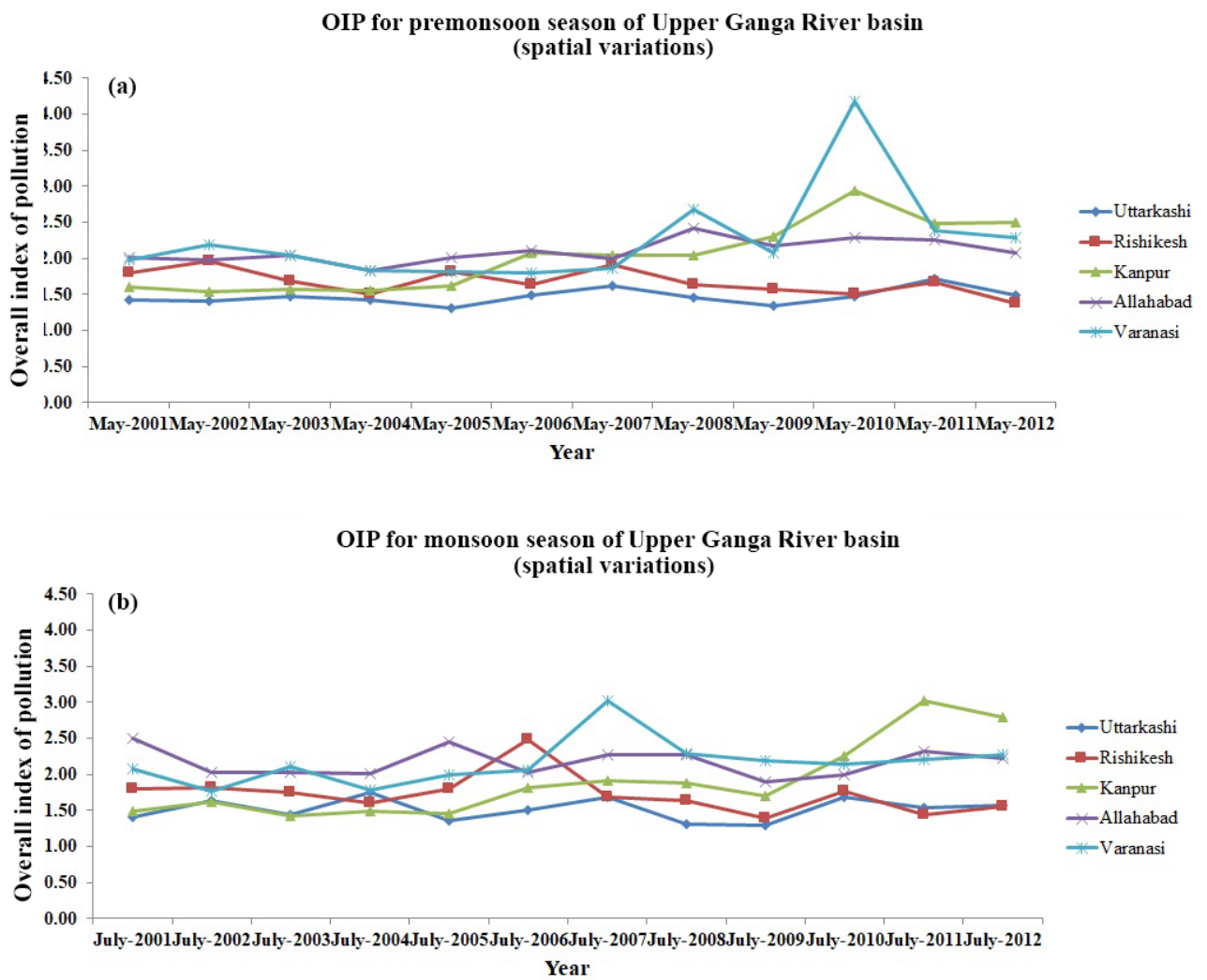

OIP for postmonsoon season of Upper Ganga River basin (spatial variations)

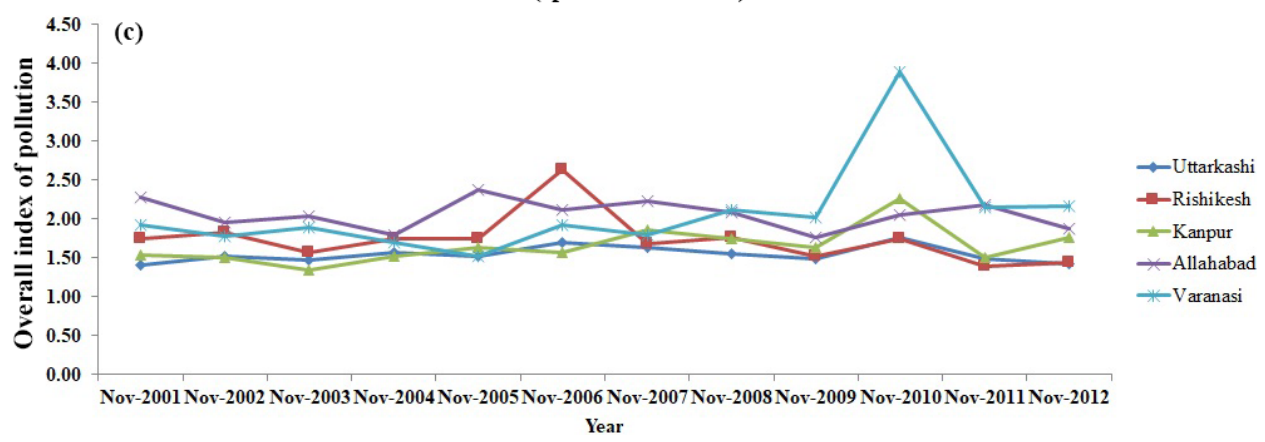

Figure 6. Spatial variations in the overall indices of pollution (OIPs) in the Upper Ganga River basin from 2001 to 2012 for the (a) premonsoon period (b) monsoon period, (c) postmonsoon period.

turbidity, generally increase during postmonsoon season due to the addition of various pollutants and sediments in the river water during monsoon period.

Water quality monitoring stations of Uttarkashi $\quad(\mathrm{PGR}=11.9 \%)$ and Rishikesh (Dehradun $\mathrm{PGR}=32.3 \%)$ are located in the foothills of the Himalayas with relatively low gross population in small towns. These stations are least influenced by human intervention among all the stations. They are mainly influenced from the generation of silts (due to steep hilly slopes) and climatic factors such as rainfall. For example, IPI for $\mathrm{pH}$ in 2001 remained at 2.76 in both the stations. In 2012 the $\mathrm{pH}$ ranged between 1.74 (postmonsoon season) and 2.09 (premonsoon season) at Uttarkashi station. At Rishikesh station it ranged between 2.09 (pre and postmonsoon season) and 2.52 (monsoon season), which is slightly better than the IPI values in 2001 . Therefore, all the water quality parameters at these stations are in the acceptable range with no significant variations in the IPI values of the parameters over time. As the Ganga River descends down to the Gangetic Plains, a large number of tributaries join the River Ganga. One of those, the River Yamuna that passes from metropolitan city of New Delhi and many other Class-I cities (population > 100000), joins the River Ganga at Allahabad. It 
carries a large amount of untreated pollutant load from both municipal and industrial areas of these cities on its way and adds to the river Ganga. During rainfall, toxic urban runoff is discharged to the river directly or through storm water drains. Similarly, water pollution at Kanpur was caused by urban domestic wastes and industries, mainly tanneries. At Varanasi river water again gets affected by municipal and industrial discharges into the river. Varanasi being the last monitoring station collects pollutants from all the above cities, and hence it is identified as the most severely polluted station in the UGRB, which keeps varying with time. In 2001, Allahabad is the most polluted station followed by Varanasi and Kanpur. However, in 2012, Kanpur is the most polluted station followed by Varanasi and Allahabad, indicating LULC changes. The water quality remained in the acceptable to slightly polluted class range.

Total population of all three cities is very high and Kanpur has the highest population (6377452) amongst them. Varanasi has the highest population density in the region. Similarly, Allahabad had a PGR of $20.6 \%$ between 2001 and 2011. These cities are the biggest centers of commercial activities in the UGRB. The main industry types in Allahabad district are glass, wire products, battery, etc., whereas Varanasi consists of textile, printing, electrical-machineryrelated industries. In the lower reaches of the Ganga River, major industrialization has occurred in and around Kanpur. Tanneries are the major types of industries in Kanpur; the majority of them are located in the Jajmau area, which is close to River Ganga. The wastewater generated from various tanning operations, e.g., soaking, liming, deliming and tanning, result in increased levels of organic loading, salinity and specific pollutants such as sulfide and chromium. These are very toxic pollutants and affect the parameters, viz. $\mathrm{BOD}$, hardness $\left(\mathrm{CaCO}_{3}\right), \mathrm{pH}$ and turbidity (Rajeswari, 2015). Hence, due to wastewater from tanneries and municipal discharges, high IPI values of hardness $\left(\mathrm{CaCO}_{3}\right)(2.10)$ and $\mathrm{pH}$ (4.81) are observed for Kanpur station in 2012. IPI values of hardness $\left(\mathrm{CaCO}_{3}\right)(1.90)$ and $\mathrm{pH}(4.81)$ at Varanasi station are just lower than Kanpur and are followed by water quality of Allahabad, which showed close IPI values of 1.97 and 4.00, respectively. These cities do not have tanneries but their urban sewage and industrial effluents affect the water quality of the river.

Other than tanneries and industries based on agriculture, textile, paper, mineral, metal and furniture are also present. Unnao is other industrial town located close to Kanpur. A large amount of municipal sewage generated in the urban residential areas and industrial effluents are discharged into the water. In total, 6087 MLD (million liters per day) of wastewater is discharged into the Ganga River. Out of the whole river basin, six sub-regions alone, namely Kanpur, Unnao, Rai-Bareeilly, Allahabad, Mirazapur and Varanasi, discharge 3019 MLD of wastewater directly or indirectly into the river. Particularly, the cities of Kanpur, Allahabad and Varanasi contribute about 598.19, 293.5 and 410.79 MLD of wastew- ater into the river respectively (CPCB, 2013; NRSC, 2014). Municipal sewage water is characterized by high BOD and total coliform bacteria count. Table 9 illustrates a very high IPI value in the BOD of Kanpur (6.67), Allahabad (2.13) and Varanasi (2.60) in the year 2012. It has increased from 2001 to 2012. Similarly in the year 2012, IPI of total coliform bacteria count is found in the range of minimum 3.90 (Allahabad) to 5.97 (Varanasi). It falls in the class of slightly polluted to polluted. F, $\mathrm{pH}$ and turbidity are the factors mainly affected by natural drivers. IPI is within the acceptable to slightly polluted range in all three stations in 2012. F and turbidity have remained in excellent and acceptable classes over the years. Various other studies have reported that the water quality of the Ganga River near Kanpur, Allahabad and Varanasi cities is highly polluted (Gowd et al., 2010; Rai et al., 2010; Sharma et al., 2014). Rapid urbanization and industrialization have highly affected the water quality of River Ganga in these districts.

\subsection{Relationship between LULC and water quality (OIP)}

Pearson's correlation analysis between OIP and different LULC classes in the UGRB helped in studying the strength of association between these variables (Table 10). In all three seasons of the year 2001, wasteland, built-up areas and agricultural lands are positively correlated, showing a significant relationship (moderate to strong association) with OIP. Water bodies have shown very weak positive correlation, whereas moderate to strong negative correlation is observed with forest class. Due to change in the LULC distribution and water quality parameters between 2001 and 2012, variations are observed in the strength of association in the year 2012. In this year, OIP showed a very strong negative and a very weak negative correlation with forest and water bodies classes respectively. A very strong positive association is observed with agricultural lands. Moderate to strong positive correlation is observed in the built-up class. Association of OIP with wasteland is in the broad range of a very weakly positive to very weakly negative correlation.

This study found that an increase in forest cover can decrease OIP due to increased aeration of flowing river water. High sediment load, generally from surface runoff, causes the increase in turbidity. Forest areas control turbidity, hardness $\left(\mathrm{CaCO}_{3}\right)$ and $\mathrm{pH}$ parameters by acting as a buffer against these parameters. Similarly, increases in the water bodies decrease OIP by diluting the pollutants with excess water, thus improving the water quality. In the UGRB, increases in OIP, i.e., deterioration of water quality, is observed with increases in the agricultural lands and built-up areas due to introduction of pollutants from various agrochemicals, municipal sewage, industrial effluents and other types of organic matter. These lower the DO level and increase BOD parameter. Correlation between wasteland and OIP are not very significant. Another study done by At- 
Table 10. Pearson's correlation coefficients relating LULC to water quality (OIP) in the Upper Ganga River basin (premonsoon, monsoon and postmonsoon seasons of 2001 and 2012).

\begin{tabular}{|c|c|c|c|c|c|c|}
\hline Stations & OIP premonsoon (2001) & $\mathrm{F} \%$ & WL \% & WB \% & $\mathrm{AG} \%$ & $\mathrm{BU} \%$ \\
\hline Uttarkashi & 1.42 & 39.3 & 10.3 & 1.4 & 0.6 & 0.2 \\
\hline Rishikesh & 1.81 & 59.8 & 18.8 & 4.8 & 13.5 & 3.2 \\
\hline Kanpur & 2.61 & 0.3 & 23.4 & 2.5 & 63.7 & 10.1 \\
\hline Allahabad & 2.02 & 1.5 & 22.1 & 3.0 & 70.5 & 2.8 \\
\hline Varanasi & 1.99 & 0.6 & 16.8 & 3.1 & 76.8 & 2.7 \\
\hline \multicolumn{2}{|c|}{ Pearson's correlation coefficients } & -0.65 & 0.87 & 0.12 & 0.71 & 0.95 \\
\hline Stations & OIP Monsoon (2001) & $\mathrm{F} \%$ & WL \% & WB $\%$ & $\mathrm{AG} \%$ & $\mathrm{BU} \%$ \\
\hline Uttarkashi & 1.41 & 39.3 & 10.3 & 1.4 & 0.6 & 0.2 \\
\hline Rishikesh & 1.80 & 59.8 & 18.8 & 4.8 & 13.5 & 3.2 \\
\hline Kanpur & 2.49 & 0.3 & 23.4 & 2.5 & 63.7 & 10.1 \\
\hline Allahabad & 2.50 & 1.5 & 22.1 & 3.0 & 70.5 & 2.8 \\
\hline Varanasi & 2.08 & 0.6 & 16.8 & 3.1 & 76.8 & 2.7 \\
\hline \multicolumn{2}{|c|}{ Pearson's correlation coefficients } & -0.77 & 0.93 & 0.15 & 0.87 & 0.69 \\
\hline Stations & OIP postmonsoon (2001) & $\mathrm{F} \%$ & WL $\%$ & WB \% & $\mathrm{AG} \%$ & $\mathrm{BU} \%$ \\
\hline Uttarkashi & 1.41 & 39.3 & 10.3 & 1.4 & 0.6 & 0.2 \\
\hline Rishikesh & 1.75 & 59.8 & 18.8 & 4.8 & 13.5 & 3.2 \\
\hline Kanpur & 2.54 & 0.3 & 23.4 & 2.5 & 63.7 & 10.1 \\
\hline Allahabad & 2.29 & 1.5 & 22.1 & 3.0 & 70.5 & 2.8 \\
\hline Varanasi & 1.92 & 0.6 & 16.8 & 3.1 & 76.8 & 2.7 \\
\hline \multicolumn{2}{|c|}{ Pearson's correlation coefficients } & -0.73 & 0.93 & 0.09 & 0.78 & 0.83 \\
\hline Stations & OIP premonsoon (2012) & $\mathrm{F} \%$ & WL \% & WB $\%$ & $\mathrm{AG} \%$ & $\mathrm{BU} \%$ \\
\hline Uttarkashi & 1.49 & 39.7 & 8.3 & 1.5 & 1.4 & 0.6 \\
\hline Rishikesh & 1.38 & 59.8 & 3.4 & 4.3 & 20.3 & 12.2 \\
\hline Kanpur & 2.51 & 0.3 & 4.7 & 2.6 & 67.0 & 25.3 \\
\hline Allahabad & 2.07 & 1.5 & 16.0 & 3.1 & 73.4 & 6.0 \\
\hline Varanasi & 2.28 & 0.7 & 6.0 & 3.3 & 79.4 & 10.5 \\
\hline \multicolumn{2}{|c|}{ Pearson's correlation coefficients } & -0.94 & 0.10 & -0.09 & 0.88 & 0.63 \\
\hline Stations & OIP monsoon (2012) & $\mathrm{F} \%$ & $\mathrm{WL} \%$ & WB $\%$ & $\mathrm{AG} \%$ & $\mathrm{BU} \%$ \\
\hline Uttarkashi & 1.58 & & 8.3 & 1.5 & 1.4 & 0.6 \\
\hline Rishikesh & 1.55 & 59.8 & 3.4 & 4.3 & 20.3 & 12.2 \\
\hline Kanpur & 2.79 & 0.3 & 4.7 & 2.6 & 67.0 & 25.3 \\
\hline Allahabad & 2.23 & 1.5 & 16.0 & 3.1 & 73.4 & 6.0 \\
\hline Varanasi & 2.27 & 0.7 & 6.0 & 3.3 & 79.4 & 10.5 \\
\hline \multicolumn{2}{|c|}{ Pearson's correlation coefficients } & -0.89 & 0.08 & -0.09 & 0.83 & 0.72 \\
\hline Stations & OIP postmonsoon (2012) & $\mathrm{F} \%$ & WL \% & WB $\%$ & $\mathrm{AG} \%$ & $\mathrm{BU} \%$ \\
\hline Uttarkashi & 1.42 & 39.7 & 8.3 & 1.5 & 1.4 & 0.6 \\
\hline Rishikesh & 1.44 & 59.8 & 3.4 & 4.3 & 20.3 & 12.2 \\
\hline Kanpur & 2.77 & 0.3 & 4.7 & 2.6 & 67.0 & 25.3 \\
\hline Allahabad & 1.87 & 1.5 & 16.0 & 3.1 & 73.4 & 6.0 \\
\hline Varanasi & 2.16 & 0.7 & 6.0 & 3.3 & 79.4 & 10.5 \\
\hline Pearson's cc & rrelation coefficients & -0.79 & -0.14 & -0.07 & 0.75 & 0.82 \\
\hline
\end{tabular}


Table 11. Multiple linear regression models for OIP and LULC classes in the Upper Ganga River basin.

\begin{tabular}{lllcr}
\hline Year & Independent variable & Regression model equation & $R^{2}$ & Adjusted $R^{2}$ \\
\hline OIP (2001) & Forest, wasteland, & OIP $=1.1354-0.6331 \mathrm{~F}+$ & 0.94 & 0.94 \\
& agricultural land and & $5.08 \mathrm{WL}-0.0828 \mathrm{AG}+$ & & \\
& built-up areas & $2.7425 \mathrm{BU}$ & \\
\hline OIP (2012) & Forest, agricultural & OIP =2.1266-1.6296 F - & 0.96 & 0.95 \\
& land and built-up areas & $0.2756 \mathrm{AG}+2.9894 \mathrm{BU}$ & & \\
\hline
\end{tabular}

tua et al. (2014) reported similar results for the study conducted on African rivers. Multiple linear regression analysis can efficiently predict the OIP using one or a combination of LULC classes (Table 11). OIP of 2001 could be predicted by the combined coverage area of forest, wasteland, agricultural land and built-up area (adjusted $R^{2}=0.94$ ), whereas OIP of 2012 could be predicted by forest, agricultural land and builtup areas (adjusted $R^{2}=0.95$ ). High $R^{2}$ and adjusted $R^{2}$ values in both the years showed a strong relationship between OIP and LULC classes of the respective models. However, these relationships may vary for different regions or time periods.

\section{Summary and conclusions}

Upper Ganga River basin has been suffering from chronic water shortages for the past few decades. Population growth is the primary driver behind gradual urbanization and industrialization in this region. In addition, infrastructure development activities and agriculture have also intensified. Hence, the natural resources of the UGRB are overexploited. Sustainable water resources planning and management by policy makers and planners require an understanding of the nexus between components of population growth, LULC transformations and water quality at both regional and local scales. A $20.45 \%$ increase in PGR leads to a $43.4 \%$ increase in builtup areas. It was identified as the most dynamic LULC class in the region followed by wasteland. The Mann-Kendall rank test revealed that water quality parameters are highly variable in time and space, with no significant trends. Even though gross rural population is much higher in the lower reaches of the river basin, the PGR is higher in the urban population of upper reaches. The water quality of the majority of the stations was the most degradable in monsoon season. The water quality of the upper reaches (Uttarkashi and Rishikesh) remained in the excellent to acceptable (1.381.81) class from 2001 to 2012, whereas it changed from the acceptable to slightly polluted class (1.87-2.79) in the lower reaches (Kanpur, Allahabad and Varanasi). In the UGRB, BOD, DO and total coliform are the parameters most influenced by anthropogenic activities. Conversely, the remaining parameters, viz. $\mathrm{pH}, \mathrm{F}$, hardness $\left(\mathrm{CaCO}_{3}\right)$ and turbidity, are mainly influenced by climatic factors. The largest increase in built-up areas of $291.8 \%$, observed in the Varanasi district, is directly related to the highest deterioration of water quality in the UGRB. But Allahabad and Kanpur were identified as the most polluted stations in 2001 and 2012 respectively. Sewage, industrial effluents and runoff from urban or rural areas introduce pollutants at these stations. Future population growth and LULC changes in the UGRB may further jeopardize their nexus with water. Forests and water bodies are negatively correlated with OIP. However, built-up and agricultural lands are positively correlated. Wasteland is not significantly correlated to OIP. Multiple linear regression models developed for UGRB could successfully predict OIP (water quality) using LULC classes. The future scope of this study comprises the understanding of hydro-ecological response of the water quality changes across the river basin. The following recommendations are made for judicious regulation and control of water quality pollution in the UGRB: (a) control of deforestation and encouraging afforestation, (b) efficient town planning for better LULC distribution in the river basin, (c) reduction in the use of agro-chemicals in the fields (use of organic alternatives), (d) proper waste disposal and management system, (e) strategies to control runoff from fields (construction of bunds/canals) and (f) spreading water pollution awareness and strict policies on pollution control.

Data availability. URLs of the dataset used in this study are as follows: SRTM DEM and time series Landsat data - https://lta. cr.usgs.gov/SRTM1Arc (USGS, 2016a), https://landsat.usgs.gov/ landsat-data-access (USGS, 2016b); published thematic maps for LULC and related reports - http://bhuvan.nrsc.gov.in/gis/thematic/ index.php (National Remote Sensing Centre, Indian Space Research Organization, India, 2016); census records and related reports http://www.censusindia.gov.in (Office of the Registrar General \& Census Commissioner, Government of India, 2017); Survey of India (SoI) topographical maps which are restricted data can be requested from SoI, Government of India (GoI) - http://www.surveyofindia. gov.in/ (SoI, 2015). Ganga river basin falls under the classified river basins of the Government of India. Therefore, any data including water quality data are restricted but can be requested through proper channels from CWC, GoI (2016): http://cwc.gov.in/. 
Author contributions. AKS designed the problem and the solution methodology in the supervision of CSPO, AM, WB and RDG. AKS collected and processed all the required data for study. AKS, SP and SS analyzed the data and prepared the figures. AKS, CSPO, AM, WB and RDG interpreted the results. AKS, SP and SS wrote and proofread the paper. All the authors reviewed the paper.

Competing interests. The authors declare that they have no conflict of interest.

Special issue statement. This article is part of the special issue "The changing water cycle of the Indo-Gangetic Plain". It is not associated with a conference.

Acknowledgements. The authors thankfully acknowledge all the support provided by Department of Civil Engineering, Indian Institute of Technology Roorkee, Uttarakhand, India. We would like to express our gratitude to the Census Department (Government of India) and Central Water Commission (CWC), New Delhi, for providing census and water quality datasets respectively. We are also grateful to anonymous reviewers and editors for their valuable suggestions that helped to improve the paper further.

Edited by: Ian Holman

Reviewed by: three anonymous referees

\section{References}

Abbasi, T. and Abbasi, S. A.: Water quality indices, Elsevier, Amsterdam, The Netherlands, 1-383, https://doi.org/10.1016/C20100-69472-7, 2012.

Akkoyunlu, A. and Akiner, M. E.: Pollution evaluation in streams using water quality indices: A case study from Turkey's Sapanca Lake Basin, Ecol. Indic., 18, 501-511, 2012.

Amarasinghe, U. A., Muthuwatta, L., Smakhtin, V., Surinaidu, L., Natarajan, R., Chinnasamy, P., Kakumanu, K. R., Prathapar, S. A., Jain, S. K., Ghosh, N. C., Singh, S., Sharma, A., Jain, S. K., Kumar, S., and Goel, M. K.: Reviving the Ganges water machine: potential and challenges to meet increasing water demand in the Ganges River Basin Colombo, Sri Lanka, International Water Management Institute (IWMI), 42 pp., IWMI Research Report 167, https://doi.org/10.5337/2016.212, 2016.

Amnell, T., Anttila, P., Maatta, A. R. A., and Salmi, T.: Detecting Trends of Annual Values of Atmospheric Pollutants by the Mann-Kendall Test and Sen's Slope Estimates, Helsinki, Finnish Meteorological Institute, 35 pp., 2002.

Attua, E. M., Ayamga, J., and Pabi, O.: Relating land use and land cover to surface water quality in the Densu River basin, Ghana, International Journal of River Basin Management, 12, 57-68, 2014.

Ballester, M. V. R., de C Victoria, D., Krusche, A. V., Coburn, R., Victoria, R. L., Richey, J. E., Logsdon, M. G., Mayorga, E., and Matricardi, E.: A remote sensing/GIS-based physical template to understand the biogeochemistry of the Ji-Parana river basin (Western Amazonia), Remote Sens. Environ., 87, 429-445, 2003.

Ban, X., Wu, Q., Pan, B., Du, Y., and Feng, Q.: Application of Composite Water Quality Identification Index on the water quality evaluation in spatial and temporal variations: a case study in Honghu Lake, China, Environ. Monit. Assess., 186, 4237-4247, 2014.

Bharati, L. and Jayakody, P.: Hydrology of the Upper Ganga River. International Water-Management Institute, Project Report No. H043412, available at: http://publications.iwmi.org/pdf/ H043412.pdf (last access: 10 May 2017), 2010.

Bhuvan Portal: Indian Space Research Organization (ISRO), Government of India, available at: http://bhuvan.nrsc.gov.in/ (last access: 17 August 2017), 2016.

Bjorklund, G., Connor, R., Goujon, A., Hellmuth, M., Moriarty, P., Rast, W., Warner K., and Winpenny J.: Demographic, economic and social drivers: Chapter 2. World water development report 3, United Nations Educational, Scientific and Cultural Organization (UNESCO), 2011.

Brivio, P. A., Doria, I., and Zilioli, E.: Aspects of spatial autocorrelation of Landsat TM data for the inventory of waste-disposal sites in rural environments, Photogramm. Eng. Remote Sens., 59, 7377-7382, 1993.

Campbell, J. B.: Introduction to Remote Sensing, 4th Edition, The Guilford Press, New York, 2007.

Census of India: Office of the Registrar General, Census of India, Census-2011, available at: http://www.censusindia.gov.in (last access: 1 June 2016), 2011.

Chalmers, A. T., Van Metre, P. C., and Callender, E.: The chemical response of particle-associated contaminants in aquatic sediments to urbanization in New England, USA, J. Contam. Hydrol., 91, 4-25, 2007.

Chapman, D.: Water quality assessment, a guide to the use of biota, sediments and water in environmental monitoring, Cambridge, University Press, 609 pp., 1992.

Chardhry, P., Sharma, M. P., Bhargava, R., Kumar, S., and Dadhwal, P. J. S.: Water quality assessment of Sukhna Lake of Chandigarh city of India, Hydro Nepal, Journal of Water, Energy and Environment, 12, 26-31, 2013.

Chen, D.: A Multi-Resolution Analysis and Classification framework for improving Land use/cover mapping from Earth Observation Data, The International Archives of the Photogrammetry, Remote Sensing and Spatial Information Sciences, 34, 11871191, 2004.

Chen, J., Zhu, X., Vogelmann, J. E., Gao, F., and Jin, S.: A simple and effective method for filling gaps in Landsat ETM+ SLC-off images, Remote Sens. Environ., 115, 1053-1064, 2011.

Congalton, R. G.: A review of assessing the accuracy of classifications of remotely sensed data, Remote Sens. Environ., 37, 35-46, 1991.

CPCB (Central Pollution Control Board): Ministry of Environment and Forests, Govt. of India. Report on Pollution Assessment: River Ganga, available at: www.cpcb.nic.in (last access: 15 September 2016), 2013.

Farzadkia, M., Djahed, B., Shahsavani, E., and Poureshg, Y.: Spatio-temporal evaluation of Yamchi Dam basin water quality using Canadian water quality index, Environ. Monit. Assess., 187, 1-15, 2015. 
Foody, G. M.: Status of land cover classification accuracy assessment, Remote Sens. Environ., 80, 185-201, 2002.

Gao, G., Liu, T., and Gu, Y.: Improved neighborhood similar pixel interpolator for filling unsacn multi-temporal Landsat ETM+ data without reference, In Geoscience and Remote Sensing Symposium (IGARSS), 2016 IEEE International, 2336-2339, IEEE, 2016.

Gebremicael, T. G., Mohamed, Y. A., van der Zaag, P., and Hagos, E. Y.: Quantifying longitudinal land use change from land degradation to rehabilitation in the headwaters of Tekeze-Atbara Basin, Ethiopia, Sci. Total Environ., 622, 1581-1589, 2017.

Gill, T., Collett, L., Armston, J., Eustace, A., Danaher, T., Scarth, P., and Phinn, S.: Geometric correction and accuracy assessment of Landsat-7 ETM+ and Landsat-5 TM imagery used for vegetation cover monitoring in Queensland, Australia from 1988 to 2007, J. Spat. Sci., 55, 273-287, 2010.

GoI (Central Water Commission, Government of India): Water quality data request from Regional Offices of Central Water Commission, Government of India, available at: http://cwc.gov. in/, last access: 9 March 2016.

Gonçalves, R. P., Assis, L. C., and Vieria, C. A. O.: Comparison of sampling methods to classification of remotely sensed images, IV International Symposium in Precision in Agriculture, 23-25, 2007.

Gowd, S. S., Reddy, M. R., and Govil, P. K.: Assessment of heavy metal contamination in soils at Jajmau (Kanpur) and Unnao industrial areas of the Ganga Plain, Uttar Pradesh, India, J. Hazard. Mater., 174, 113-121, 2010.

Gyamfi, C., Ndambuki, J. M., and Salim, R. W.: Hydrological Responses to Land Use/Cover Changes in the Olifants Basin, South Africa, Water, 8, 1-16, 2016.

Haldar, S., Mandal, S. K., Thorat, R. B., Goel, S., Baxi, K. D., Parmer, N. P., Patel, V., Basha, S., and Mody, K. H.: Water pollution of Sabarmati River a Harbinger to potential disaster, Environ. Monit. Assess., 186, 2231-2242, 2014.

Hashemian, M. S., Abkar, A. A., and Fatemi, S. B.: Study of sampling methods for accuracy assessment of classified remotely sensed data, International congress for photogrammetry and remote sensing, 1682-1750, 2004.

Hellar-Kihampa, H., De Wael, K., Lugwisha, E., and Van Grieken, R.: Water quality assessment in the Pangani River basin, Tanzania: natural and anthropogenic influences on the concentrations of nutrients and inorganic ions, International journal of river basin management, 11, 55-75, 2013.

Helsel, D. R. and Hirsch, R. M.: Statistical methods in water resources, Vol. 49, Elsevier, US Geological Survey, USA, ISBN13: $9780080875088,1992$.

Hong, C., Xiaode, Z., Mengjing, G., and Wei, W.: Land use change and its effects on water quality in typical inland lake of arid area in China, J. Environ. Biol., 37, 603-609, 2016.

Horton, R. K.: An index number system for rating water quality, Journal of Water Pollution Control Federation, 37, 300-306, 1965.

Hoseinzadeh, E., Khorsandi, H., Wei, C., and Alipour, M.: Evaluation of Aydughmush River water quality using the National Sanitation Foundation Water Quality Index (NSFWQI), River Pollution Index (RPI), and Forestry Water Quality Index (FWQI), Desalin. Water Treat., 54, 2994-3002, 2014.
IS-10500: Indian Standard Specification for Drinking Water: IS10500-1983, Indian Standards Institution, New Delhi, Gr. 6, 1983.

Islam, M. M., Lenz, O. K., Azad, A. K., Ara, M. H., Rahman, M., and Hassan, N.: Assessment of Spatio-Temporal Variations in Water Quality of Shailmari River, Khulna (Bangladesh) Using Multivariate Statistical Techniques, Journal of Geoscience and Environment Protection, 5, 1-26, 2017.

Jain, P., Sharma, J. D., Sohu, D., and Sharma, P.: Chemical analysis of drinking water of villages of Sanganer Tehsil, Jaipur District, Int. J. Environ. Sci. Technol., 2, 373-379, 2006.

Jensen, J. R.: Introductory Digital Image Processing: A Remote Sensing Perspective, 3rd Edition, Pearson Prentice Hall, Upper Saddle River, NJ, 2005.

Katyal, D., Qader, A., Ismail, A. H., and Sarma, K.: Water quality assessment of Yamuna River in Delhi region using index mapping, Interdisciplinary Environmental Review, 13, 170-186, 2012.

Kendall, M. G.: Rank correlation methods, 4th ed. Charles Griffin, London, 272 pp., ISBN-13: 978-0195208375, 1975.

Kibena, J., Nhapi, I., and Gumindoga, W.: Assessing the relationship between water quality parameters and changes in landuse patterns in the Upper Manyame River, Zimbabwe, Phys. Chem. Earth Pt. A/B/C, 67, 153-163, 2014.

Kindu, M., Schneider, T., Teketay, D., and Knoke, T.: Drivers of land use/land cover changes in Munessa-Shashemene landscape of the south-central highlands of Ethiopia, Environ. Monit. Assess., 187, 1-17, 2015.

Kiptala, J. K., Mohamed, Y., Mul, M. L., Cheema, M. J. M., and Van der Zaag, P.: Land use and land cover classification using phenological variability from MODIS vegetation in the Upper Pangani River Basin, Eastern Africa, Phys. Chem. Earth Pt. A/B/C, 66, 112-122, 2013.

Kocer, M. A. T. and Sevgili, H.: Parameters selection for water quality index in the assessment of the environmental impacts of landbased trout farms, Ecol. Indic., 36, 672-681, 2014.

Kumar, T. and Jhariya, D. C. Land quality index assessment for agricultural purpose using multi-criteria decision analysis (MCDA), Geocarto Int., 30, 822-841, 2015.

Li, J., Meng, X., Zhang, Y., Li, J., Xia, L., and Zheng, H.: Analysis of the temporal and spatial distribution of water quality in China's major river basins, and trends between 2005 and 2010, Front. Earth Sci. China, 9, 463-472, 2015.

Li, Y. L., Liu, K., Li, L., and Xu, Z. X.: Relationship of land use/cover on water quality in the Liao River basin, China, Procedia Environ. Sci., 13, 1484-1493, 2012.

Liu, J., Liu, Q., and Yang, H.: Assessing water scarcity by simultaneously considering environmental flow requirements, water quantity, and water quality, Ecol. Indic., 60, 434-441, 2016.

Liu, X. and Ding, Y.: Auxiliary pixel data selection for recovering Landsat ETM+ SLC-off images, The Egyptian Journal of Remote Sensing and Space Science, 1-12, https://doi.org/10.1016/j.ejrs.2017.08.006, 2017.

Lu, D. and Weng, Q. A survey of image classification methods and techniques for improving classification performance, Int. J. Remote Sens., 28, 823-870, 2007.

Mann, H. B.: Nonparametric tests against trend, Econometrica, Journal of the Econometric Society, 13, 245-259, 1945. 
McKee, J. E. and Wolf, H. W.: Water quality criteria, State Water Quality Control Board, Sacramento, Calif. Publication, 3-A, 93 pp., 1963.

Milovanovic, M.: Water quality assessment and determination of pollution sources along the Axios/Vardar River, Southeastern Europe, Desalination, 213, 159-173, 2007.

Muriithi, F. K.: Land use and land cover (LULC) changes in semiarid sub-watersheds of Laikipia and Athi River basins, Kenya, as influenced by expanding intensive commercial horticulture, Remote Sens. Appl., Soc. Environ., 3, 73-88, 2016.

National Remote Sensing Centre, Indian Space Research Organization, India: Bhuvan - Thematic Data dissemination, available at: http://bhuvan.nrsc.gov.in/gis/thematic/index.php, last access: 12 June 2016.

Niba, A. S. and Mafereka, S. P.: Benthic macroinvertebrate assemblage composition and distribution pattern in the upper Mthatha River, Eastern Cape, South Africa, Afr. J. Aquat. Sci., 40, 133142,2015

NRSC (National Remote Sensing Centre): Water Resources Information System (WRIS) Report, Indian Space Research Organisation (ISRO), Government of India, Report on Ganga Basin: Version 2.0, available at: http://www.india-wris.nrsc. gov.in/Publications/BasinReports/GangaBasin.pdf (last access: 26 August 2017), 2014.

Office of the Registrar General \& Census Commissioner, Government of India: Census Digital Library, available at: http://www. censusindia.gov.in, last access: 17 July 2017.

Phung, D., Huang, C., Rutherford, S., Dwirahmadi, F., Chu, C., Wang, X., Nguyen, M., Nguyen, N. H., Do, C. M., Nguyen, T. H., and Dinh, T. A. D.: Temporal and spatial assessment of river surface water quality using multivariate statistical techniques: a study in Can Tho City, a Mekong Delta area, Vietnam, Environ. Monit. Assess., 187, 1-13, 2015.

Prati, L., Pavanello, R., and Pesarin, F.: Assessment of surface water quality by a single index of pollution, Water Res., 5, 741-751, 1971.

Pullanikkatil, D., Palamuleni, L. G., and Ruhiiga, T. M.: Impact of land use on water quality in the Likangala catchment, southern Malawi, Afr. J. Aquat. Sci., 40, 277-286, 2015.

Rai, P. K., Mishra, A., and Tripathi, B. D.: Heavy metal and microbial pollution of the River Ganga: A case study of water quality at Varanasi, Aquat. Ecosyst. Health Manage., 13, 352-361, 2010.

Rai, R. K., Upadhyay, A., Ojha, C. S. P., and Singh, V. P.: The Yamuna river basin: water resources and environment, Springer Science \& Business Media, 473 pp., 2011.

Rajeswari, A.: Efficiency of effluent treatment plant and assessment of water quality parameters in tannery wastes, European Journal of Experimental Biology, 5, 49-55, 2015.

Rangeti, I., Dzwairo, B., Barratt, G. J., and Otieno, F. A. O.: Ecosystem-specific water quality indices, Afr. J. Aquat. Sci., 40, 227-234, 2015.

Rashid, I. and Romshoo, S. A.: Impact of anthropogenic activities on water quality of Lidder River in Kashmir Himalayas, Environ. Monit. Assess., 185, 4705-4719, 2013.

Russell, I. A.: Spatio-temporal variability of five surface water quality parameters in the Swartvlei estuarine lake system, South Africa, Afr. J. Aquat. Sci., 40, 119-131, 2015.
Samal, D. R. and Gedam, S. S.: Monitoring land use changes associated with urbanization: An object based image analysis approach, Eur. J. Remote Sens., 48, 85-99, 2015.

Sanchez, E., Colmenarejo, M. F., Vicente, J., Rubio, A., García, M. G., Travieso, L., and Borja, R.: Use of the water quality index and dissolved oxygen deficit as simple indicators of watersheds pollution, Ecol. Indic., 7, 315-328, 2007.

Sargaonkar, A. and Deshpande, V.: Development of an overall index of pollution for surface water based on a general classification scheme in Indian context, Environ. Monit. Assess., 89, 43-67, 2003.

Sharma, D. and Kansal, A.: Water quality analysis of River Yamuna using water quality index in the national capital territory, India (2000-2009), Appl. Water Sci., 1, 147-157, 2011.

Sharma, P., Meher, P. K., Kumar, A., Gautam, Y. P., and Mishra, K. P.: Changes in water quality index of Ganges river at different locations in Allahabad, Sustainability Water Qual. Ecol., 3, 6776, 2014

Shukla, A. K., Shukla, S., and Ojha, R.: Geospatial Technologies for Rainfall and Atmospheric Water Vapor Measurement over Arid Regions of India, in: Sustainable Water Resources Management, edited by: Chandra, S. P. O., Surampalli, R. Y., Bárdossy, A., Zhang, T. C., and Kao, C.-M., 263-292, https://doi.org/10.1061/9780784414767.ch10, 2017.

Shukla, S. and Gedam, S.: Assessing the impacts of urbanization on hydrological processes in a semi-arid river basin of Maharashtra, India, Modeling Earth Systems and Environment, 4, 1-30, 2018.

Singh, R. B. and Chandna, V.: Spatial analysis of Yamuna River water quality in pre-and post-monsoon periods, IAHS-AISH publication, 348, 8-13, 2011.

Sinha, K. and Das, P.: Assessment of water quality index using cluster analysis and artificial neural network modeling: a case study of the Hooghly River basin, West Bengal, India, Desalin. Water Treat., 54, 28-36, 2015.

Smith, V. H., Tilman, G. D., and Nekola, J. C.: Eutrophication: impacts of excess nutrient inputs on freshwater, marine, and terrestrial ecosystems, Environ. Pollut., 100, 179-196, 1999.

SoE report: Uttarakhand State Council for Science and Technology (UCOST), Dehradun, India, available at: http:// www.ucost.in/document/publication/books/env-books.pdf (last access: 12 March 2018), 2012.

SoI (Survey of India, Government of India): Map Archive \& Dissemination Centre, available at: http://www.surveyofindia.gov. in/, last access: 19 November 2015.

Sutadian, A. D., Muttil, N., Yilmaz, A. G., and Perera, B. J. C.: Development of river water quality indices - a review, Environ. Monit. Assess., 188, 1-29, 2016.

Teodosiu, C., Robu, B., Cojocariu, C., and Barjoveanu, G.: Environmental impact and risk quantification based on selected water quality indicators, Nat. Hazard., 75, 89-105, 2013.

Tsihrintzis, V. A. and Hamid, R.: Modeling and management of urban stormwater runoff quality: a review, Water Resour. Manage., 11, 136-164, 1997.

Tu, J.: Spatially varying relationships between land use and water quality across an urbanization gradient explored by geographically weighted regression, Appl. Geogr., 31, 376-392, 2011.

Tyagi, S., Sharma, B., Singh, P., and Dobhal, R.: Water quality assessment in terms of water quality index, American Journal of Water Resources, 1, 34-38, 2013. 
USGS (United States Geological Survey): SRTM DEM data, Shuttle Radar Topography Mission (SRTM) 1 Arc-Second Global, available at: https://lta.cr.usgs.gov/SRTM1Arc, last access: 23 March 2016a.

USGS (United States Geological Survey): Time series Landsat data: Landsat Data Access - Landsat Missions - USGS, available at: https://landsat.usgs.gov/landsat-data-access, last access: 16 May 2016b.

USGS (United States Geological Survey): United States of America, available at: http://www.usgs.gov/ (last access: 25 September 2015), 2016c.

USGS (United States Geological Survey): SLC-off Products: Background, https://landsat.usgs.gov/slc-products-background, last access: 12 March 2018.

Watershed Atlas of India: Ministry of Water Resources, Govt. of India, availaable at: http://cgwb.gov.in/watershed/ (last access: 10 March 2018), 2014.

Wijaya, A., Marpu, P. R., and Gloaguen, R.: Geostatistical Texture Classification of Tropical Rainforest in Indonesia (in CD ROM), ISPRS International Symposium on Spatial Data Quality, ITC Enschede, the Netherlands, 2007.

Wilson, C. O.: Land use/land cover water quality nexus: quantifying anthropogenic influences on surface water quality, Environ. Monit. Assess., 187, 1-23, 2015.
Xiaodong, N., Zhang, S., Zhang, H., Li, X., Yu, H., and Liu, C.: Integrating TM and ancillary geographical data with classification trees for land cover classification of marsh area, Chinese Geogr. Sci., 19, 177-185, 2009.

Yadav, N. S., Kumar, A., and Sharma, M. P.: Ecological health assessment of Chambal River using water quality parameters, Journal of Integrated Science and Technology, 2, 52-56, 2014.

Yang, F., Xu, Z., Zhu, Y., He, C., Wu, G., Qiu, J. R., Fu, Q., and Liu, Q.: Evaluation of agricultural nonpoint source pollution potential risk over China with a Transformed-Agricultural Nonpoint Pollution Potential Index method, Environ. Technol., 34, 29512963, 2013.

Yu, S., Xu, Z., Wu, W., and Zuo, D.: Effect of land use types on stream water quality under seasonal variation and topographic characteristics in the Wei River basin, China, Ecol. Indic., 60, 202-212, 2016.

Zhu, X. and Liu, D.: MAP-MRF approach to Landsat ETM+ SLCOff image classification, IEEE Trans. Geosci. Remote Sens., 52, 1131-1141, 2014.

Zhu, X., Gao, F., Liu, D., and Chen, J.: A modified neighborhood similar pixel interpolator approach for removing thick clouds in Landsat images, IEEE Geosci. Remote Sens. Lett., 9, 521-525, 2012. 